Article

\title{
Benzophenone and Benzoylphloroglucinol Derivatives from Hypericum sampsonii with Anti-Inflammatory Mechanism of Otogirinin A
}

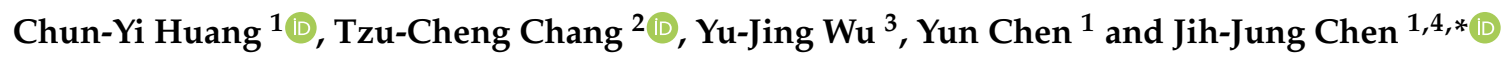 \\ 1 School of Pharmaceutical Sciences, Faculty of Pharmacy, National Yang-Ming University, \\ Taipei 11221, Taiwan; jimmyhuang9289@gmail.com (C.-Y.H.); joy0710082035@gmail.com (Y.C.) \\ 2 Department of Forestry and Natural Resources, National Ilan University, Yilan City 26047, Taiwan; \\ tcchang@ems.niu.edu.tw \\ 3 Institute of Pharmacology, National Yang-Ming University, Taipei 11221, Taiwan; kittylv199315@gmail.com \\ 4 Department of Medical Research, China Medical University Hospital, China Medical University, \\ Taichung 404332, Taiwan \\ * Correspondence: chenjj@ym.edu.tw; Tel.: +886-2-2826-7195
}

Academic Editor: Norbert Latruffe

Received: 1 September 2020; Accepted: 27 September 2020; Published: 28 September 2020

\begin{abstract}
Three new compounds, 4-geranyloxy-2-hydroxy-6-isoprenyloxybenzophenone (1), hypericumone A (2) and hypericumone B (3), were obtained from the aerial parts of Hypericum sampsonii, along with six known compounds (4-9). The structures of these compounds were determined through spectroscopic and MS analyses. Hypericumone A (2), sampsonione J (8) and otogirinin A (9) exhibited potent inhibition ( $\mathrm{IC}_{50}$ values $\leq 40.32 \mu \mathrm{M}$ ) against lipopolysaccharide (LPS)-induced nitric oxide (NO) generation. Otogirinin A (9) possessed the highest inhibitory effect on $N O$ production with $\mathrm{IC}_{50}$ value of $32.87 \pm 1.60 \mu \mathrm{M}$. The well-known proinflammatory cytokine, tumor necrosis factor-alpha (TNF- $\alpha$ ) was also inhibited by otogirinin A (9). Western blot results demonstrated that otogirinin A (9) downregulated the high expression of inducible nitric oxide synthase (iNOS). Further investigations on the mechanism showed that otogirinin A (9) blocked the phosphorylation of MAPK/JNK and I $\mathrm{K} B \alpha$, whereas it showed no effect on the phosphorylation of MAPKs/ERK and p38. In addition, otogirinin A (9) stimulated anti-inflammatory M2 phenotype by elevating the expression of arginase 1 and Krüppel-like factor 4 (KLF4). The above results suggested that otogirinin A (9) could be considered as potential compound for further development of NO production-targeted anti-inflammatory agent.
\end{abstract}

Keywords: Hypericum sampsonii; Hypericaceae; structure elucidation; benzophenone; benzoylphloroglucinol derivative; anti-inflammatory activity

\section{Introduction}

Hypericum sampsonii Hance (Hypericaceae) has been used as a traditional medicine herb for reducing blood stasis, relieving swelling and detoxification in Taiwan [1,2]. Diverse xanthones [3-5], benzophenones [6-8], bisanthraquinones [9], flavonoids [9,10] and polyprenylated phloroglucinols [1,11-15], and their derivatives have been isolated from this species in the past studies. Many of these isolated compounds show cytotoxic [3,14], anti-HIV [13], antibacterial [4,8], antitumor [10] and anti-inflammatory [10] activities. Abnormal inflammatory response causes a variety of diseases including asthma, Alzheimer's disease, rheumatoid arthritis and even cancer [16]. Macrophages are the primary immune cells which secrete nitric oxide (NO), a mediator in the inflammatory response involved in host defense [17]. Suppression of the abnormal activation of macrophages by drugs has 
been suggested as a way to ameliorate inflammatory diseases. In our studies on the anti-inflammatory constituents of Chinese herbal medicines, many species have been screened for anti-inflammatory effect, and H. sampsonii was found to be an active species. Sampsoninone J (8) and otogirinin A (9) belong to the polyprenylated benzoylphloroglucinol derivatives with an unusual adamantyl skeleton. According to past studies, there was no biologic activity report for $\mathbf{8}$ and $\mathbf{9}$, except that $\mathbf{8}$ showed no significant cytotoxicity against P338 cell line [18]. However, their analogous benzoylphloroglucinol derivatives, garcimultiflorone G [19] and sampsonione B [20] was reported to exhibit anti-inflammatory activity. This report depicts the structural elucidation of three new Compounds 1-3, the inhibitory activities of all isolated compounds against LPS-induced NO generation and the anti-inflammatory mechanism of otogirinin A (9).

\section{Results and Discussion}

\subsection{Effect of Different Fractions of $\mathrm{MeOH}$ Extract and Isolation of Compounds}

The $n$-hexane fraction of the $\mathrm{MeOH}$ extract of $H$. sampsonii showed the most potent inhibition against lipopolysaccharide (LPS)-induced nitric oxide (NO) accumulation in RAW264.7 macrophages, while $\mathrm{H}_{2} \mathrm{O}$ fraction had no effect on $\mathrm{NO}$ generation (Figure 1). The murine macrophage cell line, RAW264.7, is often used to initially screen natural products for anti-inflammatory activity [21,22]. Based on this reason, we carried out the chromatographic purification of the hexane-soluble fraction of $\mathrm{MeOH}$ extracts of aerial parts of $H$. sampsonii on a silica gel column and preparative TLC afforded three undescribed (1-3) and six known compounds (4-9) (Figure 2).

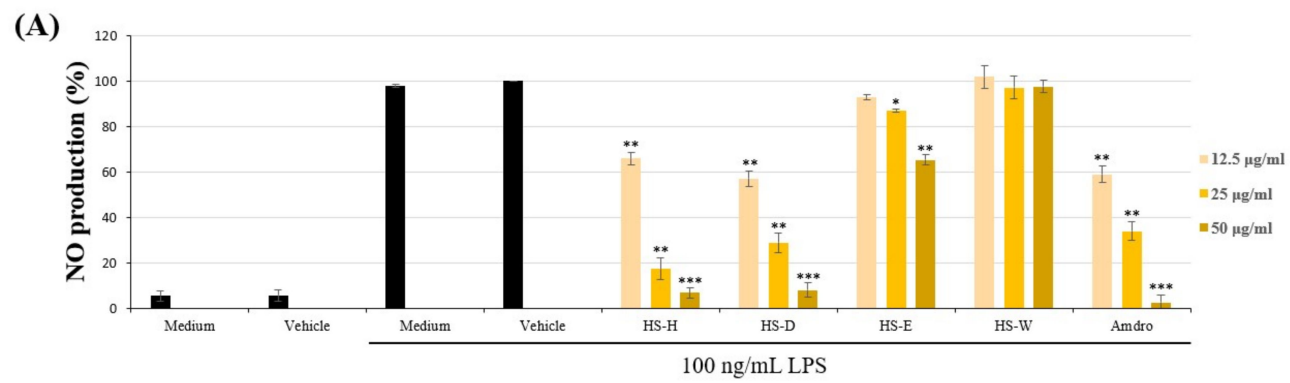

(B)

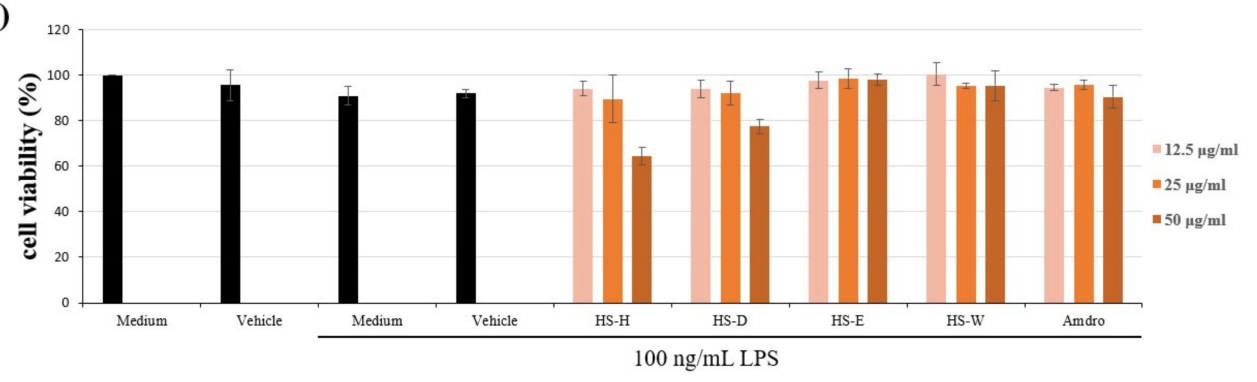

Figure 1. Effects of different partition fractions (HS-H, HS-D, HS-E and HS-W represent $n$-hexane, dichloromethane, ethyl acetate and $\mathrm{H}_{2} \mathrm{O}$ fractions, respectively) of crude $\mathrm{MeOH}$ extracts from Hypericum sampsonii on (A) nitric oxide (NO) production and (B) cytotoxicity in lipopolysaccharide (LPS)-induced RAW264.7 macrophages. Data expressed as means $\pm \operatorname{SEM}(n=3)$. Asterisks indicate significant differences $\left({ }^{*} p<0.05,{ }^{* *} p<0.01\right.$ and $\left.{ }^{* * *} p<0.001\right)$ from the (media + DMSO + LPS) control group. 


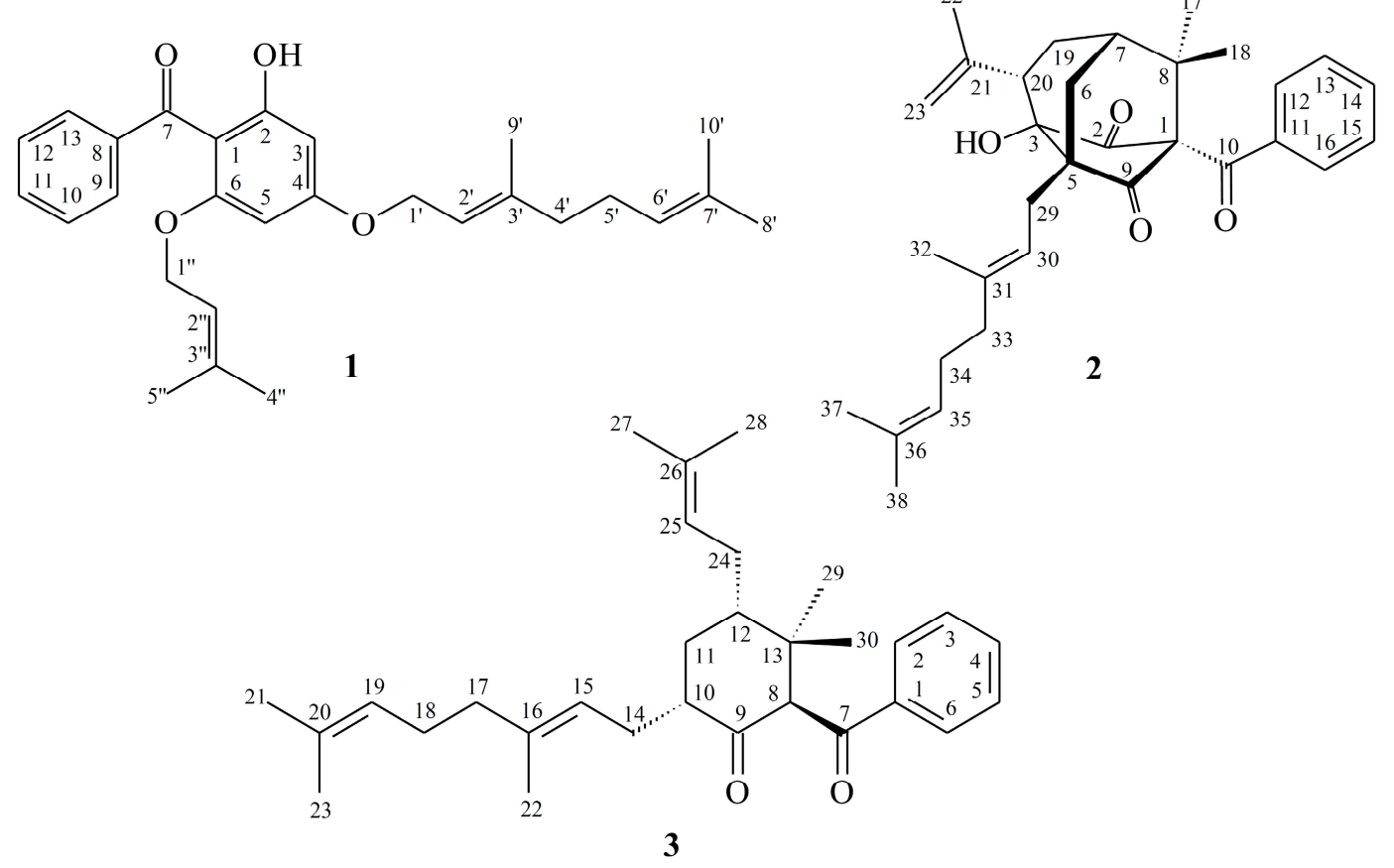<smiles>COc1ccc2oc3cccc(O)c3c(=O)c2c1</smiles><smiles>COc1ccc2oc3ccccc3c(=O)c2c1</smiles><smiles>CC(C)=CCC/C(C)=C/COc1cc(O)c(C(=O)c2ccccc2)c(O)c1</smiles><smiles>CC(C)=CCc1c(O)c(C(=O)c2ccccc2)c2c3c1OC(C)(C)CC3CC(C)(C)O2</smiles>

6

7

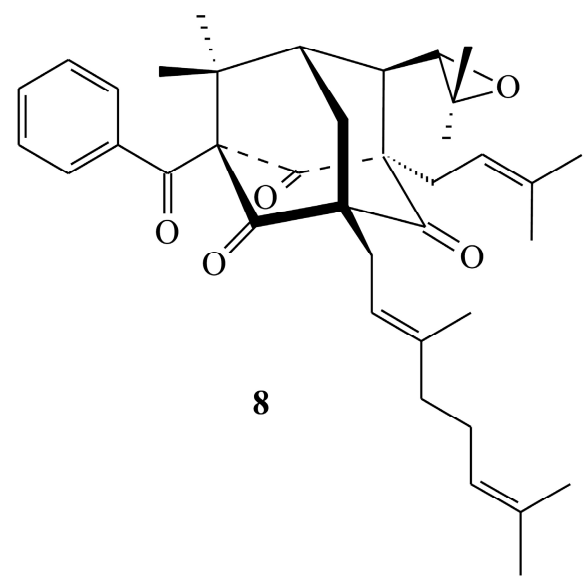

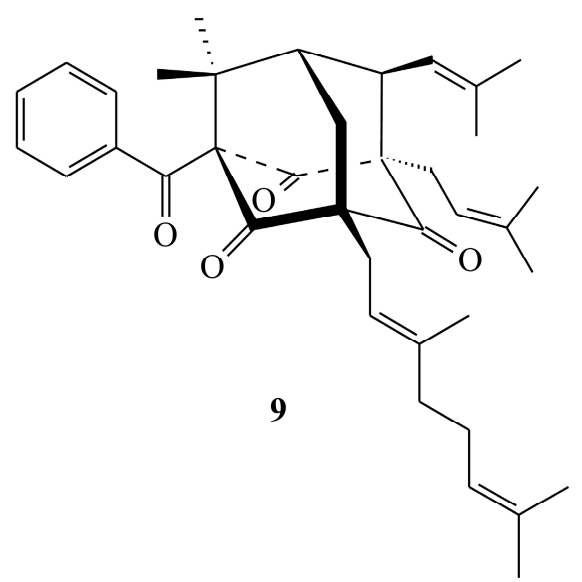

Figure 2. Chemical structures of Compounds 1-9 isolated from H. sampsonii. 
Compound 1 was isolated as yellowish oil. Its molecular formula, $\mathrm{C}_{28} \mathrm{H}_{34} \mathrm{O}_{4}$, was determined on the basis of the negative HR-ESI-MS ion at $m / z 433.2370[\mathrm{M}-\mathrm{H}]^{-}$(calcd 433.2379) and supported by the ${ }^{1} \mathrm{H}$ - and ${ }^{13} \mathrm{C}-\mathrm{NMR}$ data. The presence of conjugated carbonyl group was revealed by the band at $1618 \mathrm{~cm}^{-1}$ in the IR spectrum and was confirmed by signal at $\delta 199.6$ in the ${ }^{13} \mathrm{C}-\mathrm{NMR}$ spectrum. The ${ }^{1} \mathrm{H}$ and ${ }^{13} \mathrm{C}-\mathrm{NMR}$ data of 1 showed the presence of a benzoyl group [ $\delta_{\mathrm{H}} 7.35(2 \mathrm{H}$, br t, $J=7.5 \mathrm{~Hz}, \mathrm{H}-10$ and $\mathrm{H}-12), 7.43(1 \mathrm{H}$, br t, $J=7.5 \mathrm{~Hz}, \mathrm{H}-11)$ and $7.48\left(2 \mathrm{H}\right.$, br d, $J=7.5 \mathrm{~Hz}, \mathrm{H}-9$ and H-13); $\delta_{\mathrm{C}} 127.4(\mathrm{C}-9)$, 127.4 (C-13), 127.5 (C-10), 127.5 (C-12), 130.2 (C-11) and $142.3(\mathrm{C}-8)$ ], a hydroxyl group [ $\delta_{\mathrm{H}} 12.37(1 \mathrm{H}, \mathrm{s}$, $\mathrm{D}_{2} \mathrm{O}$ exchangeable, $\left.\left.\mathrm{OH}-2\right)\right]$, a geranyloxy group $\left[\delta_{\mathrm{H}} 1.62,1.69\right.$ and 1.76 (each $3 \mathrm{H}$, each s, $\mathrm{H}-10^{\prime}, \mathrm{H}-8^{\prime}$ and $\left.\mathrm{H}-9^{\prime}\right), 2.11\left(2 \mathrm{H}\right.$, br t, $\left.J=6.5 \mathrm{~Hz}, \mathrm{H}-4^{\prime}\right), 2.14\left(2 \mathrm{H}, \mathrm{m}, \mathrm{H}-5^{\prime}\right), 4.58\left(2 \mathrm{H}, \mathrm{d}, J=6.5 \mathrm{~Hz}, \mathrm{H}-1^{\prime}\right), 5.10(1 \mathrm{H}, \mathrm{br} \mathrm{t}$, $\left.J=6.5 \mathrm{~Hz}, \mathrm{H}-6^{\prime}\right)$ and $5.48\left(1 \mathrm{H}, \mathrm{br} \mathrm{t}, J=6.5 \mathrm{~Hz}, \mathrm{H}-2^{\prime}\right) ; \delta_{\mathrm{C}} 16.7\left(\mathrm{C}-9^{\prime}\right), 17.7\left(\mathrm{C}-10^{\prime}\right), 25.7\left(\mathrm{C}-8^{\prime}\right), 26.3\left(\mathrm{C}-5^{\prime}\right)$, $39.5\left(\mathrm{C}-4^{\prime}\right), 65.2\left(\mathrm{C}-1^{\prime}\right), 118.4\left(\mathrm{C}-2^{\prime}\right), 123.6\left(\mathrm{C}-6^{\prime}\right), 131.9\left(\mathrm{C}-7^{\prime}\right)$ and $\left.142.3\left(\mathrm{C}-3^{\prime}\right)\right]$, an isoprenyloxy group [ $\delta_{\mathrm{H}} 1.50$ and 1.57 (each $3 \mathrm{H}$, each $\mathrm{s}, \mathrm{H}-5^{\prime \prime}$ and $\left.\mathrm{H}-4^{\prime \prime}\right), 4.18\left(2 \mathrm{H}, \mathrm{d}, J=6.0 \mathrm{~Hz}, \mathrm{H}-\mathrm{1}^{\prime \prime}\right)$ and $4.62(1 \mathrm{H}, \mathrm{br} \mathrm{t}$, $\left.J=6.0 \mathrm{~Hz}, \mathrm{H}-2^{\prime \prime}\right) ; \delta_{\mathrm{C}} 18.0\left(\mathrm{C}-5^{\prime \prime}\right), 25.5\left(\mathrm{C}-4^{\prime \prime}\right), 65.1\left(\mathrm{C}-1^{\prime \prime}\right), 118.4\left(\mathrm{C}-2^{\prime \prime}\right)$ and $\left.137.0\left(\mathrm{C}-3^{\prime \prime}\right)\right]$ and two meta-coupling aromatic protons $\left[\delta_{\mathrm{H}} 5.93\right.$ and 6.16 (each $1 \mathrm{H}$, each $\mathrm{d}, J=2.5 \mathrm{~Hz}, \mathrm{H}-5$ and $\mathrm{H}-3$ ); $\delta_{\mathrm{C}} 92.5$ (C-5) and 94.1 (C-3)]. The signal at $\delta_{\mathrm{H}} 12.37$ exhibited a chelated hydroxyl group with the carbonyl group. These indicated there is a typical benzophenone structure in Compound 1 [15]. Comparison of the ${ }^{1} \mathrm{H}$ - and ${ }^{13} \mathrm{C}$-NMR data of 1 with those of 4-geranyloxy-2,6-dihydroxybenzophenone [23] suggested that their structures were closely related, except that the 6-isoprenyloxy group of 1 replaced the 6-hydroxy group of 4-geranyloxy-2,6-dihydroxybenzophenone [23]. This was supported by both HMBC correlations between $\mathrm{H}-1^{\prime \prime}\left(\delta_{\mathrm{H}} 4.18\right)$ and C-6 $\left(\delta_{\mathrm{C}} 161.4\right), \mathrm{C}-2^{\prime \prime}\left(\delta_{\mathrm{C}} 118.4\right)$ and C-3 ${ }^{\prime \prime}\left(\delta_{\mathrm{C}} 137.0\right)$ and NOESY correlations between $\mathrm{H}-1^{\prime \prime}\left(\delta_{\mathrm{H}} 4.18\right)$ and $\mathrm{H}-5\left(\delta_{\mathrm{H}} 5.93\right)$. This was supported by ${ }^{1} \mathrm{H}-{ }^{1} \mathrm{H}$ COSY, HSQC, NOESY (Figure 3) and HMBC (Figure 3) experiments. On the basis of the above data, the structure of $\mathbf{1}$ was elucidated as 4-geranyloxy-2-hydroxy-6-isoprenyloxy- benzophenone.
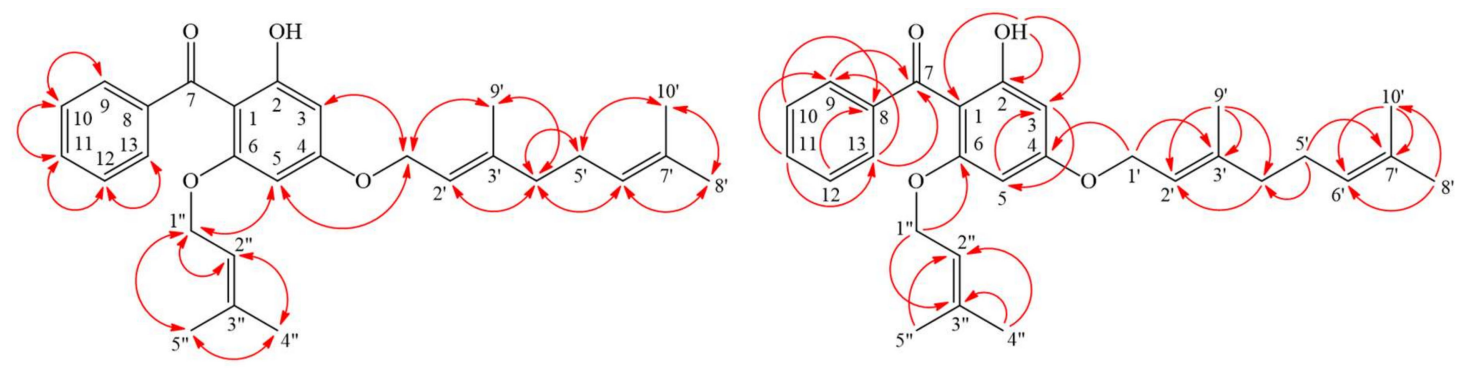

Figure 3. Key NOESY ( $)$ and HMBC $(>)$ correlations of $\mathbf{1}$. NOESY-nuclear Overhauser effect spectrometry; $\mathrm{HMBC}$ - heteronuclear multiple-bond correlation.

Compound 2 was obtained as white amorphous powder, $[\alpha]_{\mathrm{D}}^{25}=-43.5\left(c, 0.16, \mathrm{CHCl}_{3}\right)$. The ESI-MS demonstrated the quasi-molecular ion $[\mathrm{M}+\mathrm{Na}]^{+}$at $m / z 511$, implying a molecular formula of $\mathrm{C}_{32} \mathrm{H}_{40} \mathrm{O}_{4}$, which was confirmed by the HR-ESI-MS $\left(m / z 511.2823[\mathrm{M}+\mathrm{Na}]^{+}\right.$, calcd 511.2824$)$ and by the ${ }^{1} \mathrm{H}-$ and ${ }^{13} \mathrm{C}-\mathrm{NMR}$ data. The presence of carbonyl groups was revealed by the bands at 1722 and $1684 \mathrm{~cm}^{-1}$ in the IR spectrum and was confirmed by the signals at $\delta 193.3,211.6$ and 212.3 in the ${ }^{13} \mathrm{C}$-NMR spectrum. The ${ }^{1} \mathrm{H}$ - and ${ }^{13} \mathrm{C}-\mathrm{NMR}$ data of 2 showed the presence of a benzoyl group [ $\delta_{\mathrm{H}} 7.33(2 \mathrm{H}$, br dd, $J=8.4,7.4 \mathrm{~Hz}, \mathrm{H}-13$ and H-15), $7.45(1 \mathrm{H}$, br t, $J=7.4 \mathrm{~Hz}, \mathrm{H}-14)$ and $7.56(2 \mathrm{H}, \mathrm{br} \mathrm{d}, J=8.4$ $\mathrm{Hz}, \mathrm{H}-12$ and $\mathrm{H}-16) ; \delta_{\mathrm{C}} 128.1$ (C-13), 128.1 (C-15), 129.1 (C-12), 129.1 (C-16), 132.8 (C-14) and 134.5 $(\mathrm{C}-11)]$, a hydroxyl group $\left[\delta_{\mathrm{H}} 3.38\left(1 \mathrm{H}, \mathrm{s}, \mathrm{D}_{2} \mathrm{O}\right.\right.$ exchangeable, $\left.\left.\mathrm{OH}-3\right)\right]$, a geranyl group $\left[\delta_{\mathrm{H}} 1.62,1.68\right.$ and 1.69 (each $3 \mathrm{H}$, each s, H-37, H-38 and H-32), 2.11 (2H, m, H-33), 2.14 (2H, m, H-34), 2.58 (2H, m, $\mathrm{H}-29), 5.10(1 \mathrm{H}$, br t, $J=6.7 \mathrm{~Hz}, \mathrm{H}-35)$ and $5.40(1 \mathrm{H}$, br t, $J=7.5 \mathrm{~Hz}, \mathrm{H}-30) ; \delta_{\mathrm{C}} 16.2(\mathrm{C}-32), 17.7$ (C-37), 25.8 (C-38), 26.3 (C-29), 26.4 (C-34), 40.2 (C-33), 118.5 (C-30), 124.1 (C-35), 131.7 (C-36) and 139.0 (C-31)], a prop-1-en-2-yl group $\left[\delta_{\mathrm{H}} 1.85(3 \mathrm{H}, \mathrm{s}, \mathrm{H}-22), 5.01(1 \mathrm{H}, \mathrm{br} \mathrm{s}, \mathrm{H}-23)\right.$ and $5.25(1 \mathrm{H}, \mathrm{br} \mathrm{s}, \mathrm{H}-23) ; \delta_{\mathrm{C}} 21.7$ (C-22), 118.5 (C-23) and 142.5 (C-21)] and two methyl groups $\left[\delta_{\mathrm{H}} 1.36,1.44\right.$ (each $3 \mathrm{H}$, each s, H-17 and $\mathrm{H}-18) ; \delta_{\mathrm{C}} 21.7$ (C-17) and 24.5 (C-18)]. Comparison of the ${ }^{1} \mathrm{H}-$ and ${ }^{13} \mathrm{C}-\mathrm{NMR}$ data of 2 with those of norsampsone E [24] suggested that their structures were closely related, except that the benzoyl group 
at C-1 of 2 replaced the 1-isobutyryl group of norsampsone E [24]. This was supported by both HMBC correlations between $\mathrm{H}-12\left(\delta_{\mathrm{H}} 7.56\right)$ and $\mathrm{C}-10\left(\delta_{\mathrm{C}} 193.3\right), \mathrm{C}-14\left(\delta_{\mathrm{C}} 132.8\right)$ and $\mathrm{C}-16\left(\delta_{\mathrm{C}} 129.1\right)$ and ROESY correlations between $\mathrm{H}-12\left(\delta_{\mathrm{H}} 7.56\right)$ and $\mathrm{H}-17\left(\delta_{\mathrm{H}} 1.36\right)$. To further confirm the relative configuration of 2, a computer-assisted 3D structure was obtained by using the molecular-modeling program CS CHEM 3D Ultra 12.0, with MM2 force-field calculations for energy minimization. The calculated distances

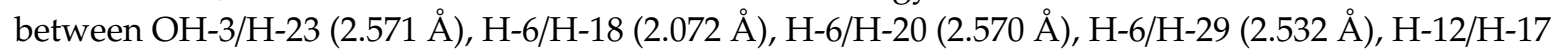
$(2.557 \AA)$ are all less than $4 \AA$ (Figure 4$)$. This is consistent with the well-defined ROESY observed for each of these $\mathrm{H}$-atom pairs. The ${ }^{1} \mathrm{H}$ - and ${ }^{13} \mathrm{C}$-NMR resonances were fully assigned by ${ }^{1} \mathrm{H}-{ }^{1} \mathrm{H}$ COSY, HSQC, ROESY and HMBC experiments (Figure 5). On the basis of the above data, the structure of 2 was elucidated as shown in Figure 2 and named hypericumone A.

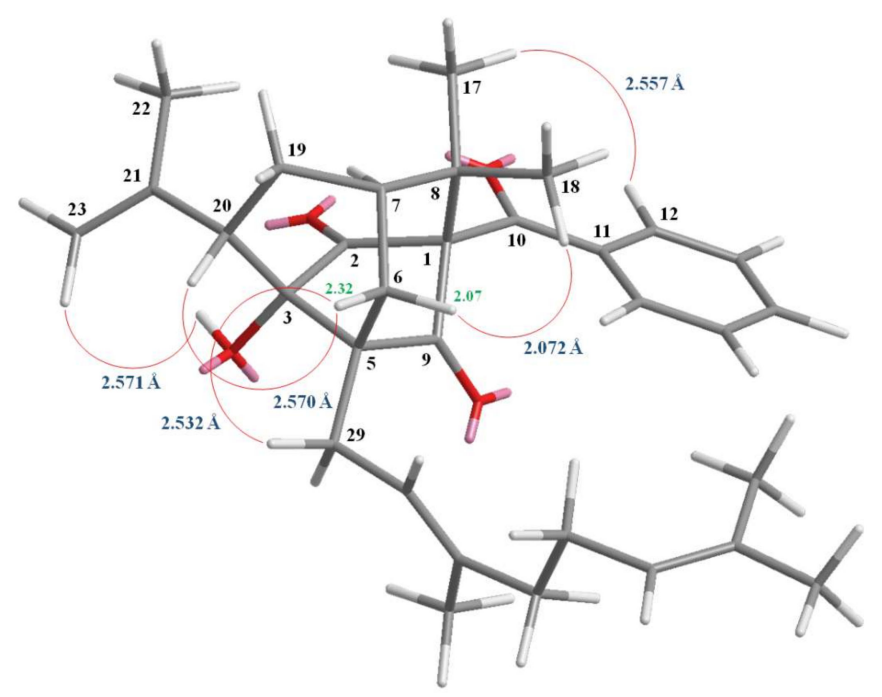

Figure 4. Selected rotating frame nuclear Overhauser effect spectrometry (ROESY) correlations and relative configuration of 2 .

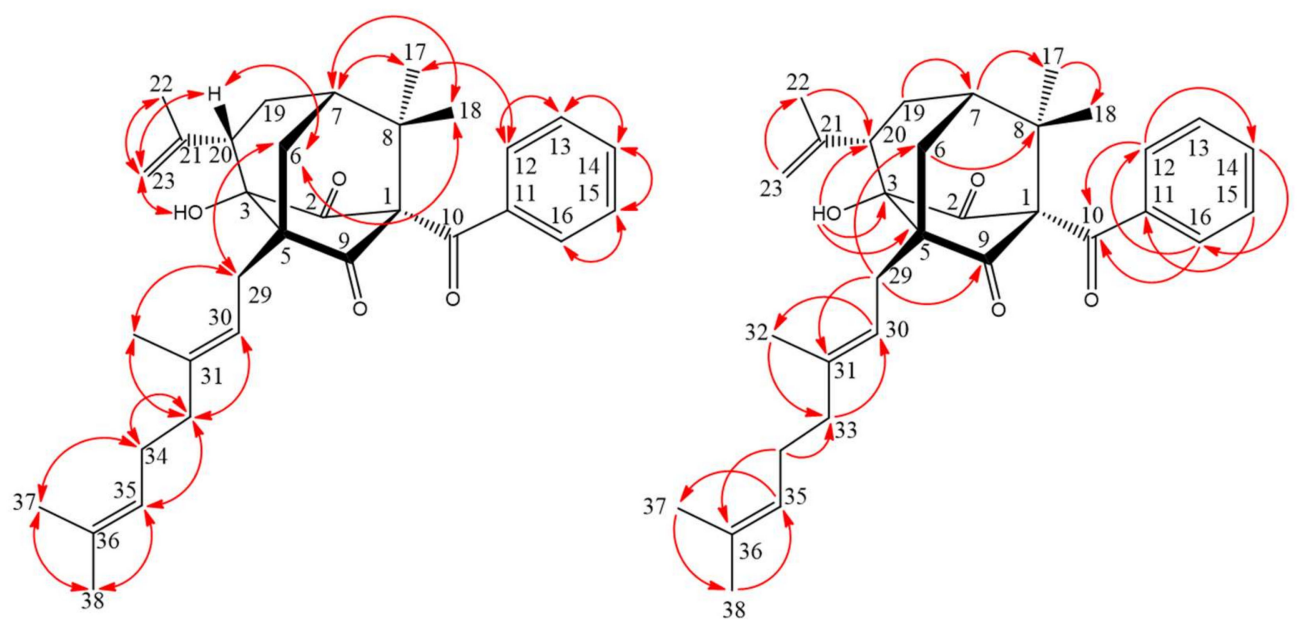

Figure 5. Key NOESY $(\longrightarrow)$ and HMBC $(\longrightarrow)$ correlations of 2.

Compound 3 was isolated as colorless oil, $[\alpha]_{\mathrm{D}}^{25}=+326.4\left(c 0.15, \mathrm{CHCl}_{3}\right)$. Its molecular formula, $\mathrm{C}_{30} \mathrm{H}_{42} \mathrm{O}_{2}$, was determined on the basis of the positive HR-ESI-MS $\left(\mathrm{m} / z\right.$ 457.3086 [M + Na] ${ }^{+}$, calcd 457.3083) and supported by the ${ }^{1} \mathrm{H}$ - and ${ }^{13} \mathrm{C}-\mathrm{NMR}$ data. The IR spectrum displayed the presence of carbonyl groups (1707 and $1672 \mathrm{~cm}^{-1}$ ), which was confirmed by the signals at $\delta 196.7$ and 208.4 in the ${ }^{13} \mathrm{C}$-NMR spectrum. The ${ }^{1} \mathrm{H}$ - and ${ }^{13} \mathrm{C}-\mathrm{NMR}$ data of 3 showed the presence of a benzoyl group $\left[\delta_{\mathrm{H}} 7.45(2 \mathrm{H}\right.$, br t, $J=7.5 \mathrm{~Hz}, \mathrm{H}-3$ and H-5), $7.55(1 \mathrm{H}$, br t, $J=7.5 \mathrm{~Hz}, \mathrm{H}-4)$ and $7.99(2 \mathrm{H}$, br d, $J=7.5 \mathrm{~Hz}$, 
H-2 and H-6); $\delta_{\mathrm{C}} 128.6$ (C-3), 128.6 (C-5), 128.7 (C-2), 128.7 (C-6), 133.2 (C-4) and 138.5 (C-1)], a geranyl group $\left[\delta_{\mathrm{H}} 1.58,1.59\right.$ and 1.66 (each $3 \mathrm{H}$, each $\mathrm{s}, \mathrm{H}-22, \mathrm{H}-23$ and $\left.\mathrm{H}-21\right), 1.95(2 \mathrm{H}, \mathrm{m}, \mathrm{H}-17), 1.98(1 \mathrm{H}$, m, H-14), 2.02 (2H, m, H-18), $2.32(1 \mathrm{H}, \mathrm{m}, \mathrm{H}-14), 5.05(1 \mathrm{H}, \mathrm{br} \mathrm{t}, J=7.6 \mathrm{~Hz}, \mathrm{H}-15)$ and $5.07(1 \mathrm{H}, \mathrm{br} \mathrm{t}$, $J=6.8 \mathrm{~Hz}, \mathrm{H}-19) ; \delta_{\mathrm{C}} 16.2$ (C-22), 17.7 (C-23), 25.7 (C-21), 26.8 (C-18), 27.4 (C-14), 39.8 (C-17), 121.6 (C-15), 124.3 (C-19), 131.3 (C-20) and 136.7 (C-16)], an isoprenyl group [ $\delta_{\mathrm{H}} 1.60(3 \mathrm{H}, \mathrm{s}, \mathrm{H}-28), 1.67(1 \mathrm{H}$, $\mathrm{m}, \mathrm{H}-24), 1.73(3 \mathrm{H}, \mathrm{s}, \mathrm{H}-27), 2.15(1 \mathrm{H}, \mathrm{m}, \mathrm{H}-24)$ and $5.21(1 \mathrm{H}, \mathrm{br} \mathrm{t}, J=7.4 \mathrm{~Hz}, \mathrm{H}-25) ; \delta_{\mathrm{C}} 17.8(\mathrm{C}-28)$, 25.8 (C-27), 28.1 (C-24), 123.6 (C-25) and 132.4 (C-26)], two methyl groups [ $\delta_{\mathrm{H}} 0.91,0.99$ (each $3 \mathrm{H}$, each $\mathrm{s}, \mathrm{H}-29$ and $\mathrm{H}-30) ; \delta_{\mathrm{C}} 22.1(\mathrm{C}-29)$ and $\left.26.1(\mathrm{C}-30)\right]$ and cyclohexanone core structure $\left[\delta_{\mathrm{H}} 1.14(1 \mathrm{H}, \mathrm{m}\right.$, $\left.\mathrm{H}_{\alpha}-11\right), 2.20\left(1 \mathrm{H}, \mathrm{m}, \mathrm{H}_{\beta}-11\right), 2.64(1 \mathrm{H}, \mathrm{m}, \mathrm{H}-12), 2.88(1 \mathrm{H}, \mathrm{m}, \mathrm{H}-10), 4.35(1 \mathrm{H}, \mathrm{s}, \mathrm{H}-8) ; \delta_{\mathrm{C}} 34.5(\mathrm{C}-11)$, 40.3 (C-12), 43.3 (C-13), 47.6 (C-10), 72.1 (C-8) and 208.4 (C-9)]. Comparison of the ${ }^{1} \mathrm{H}-$ and ${ }^{13} \mathrm{C}-\mathrm{NMR}$ data of 3 with those of norsampsone B [25] suggested that their structures were closely related, except that the 10-geranyl group and $\mathrm{H}-10$ of 3 replaced the isoprenyl and 5-methylhex-4-enoyl groups at C-10 of norsampsone B [25]. This was supported by both HMBC correlations between H-14 $\left(\delta_{\mathrm{H}} 1.98\right.$ and 2.32) and C-9 $\left(\delta_{C} 208.4\right), C-10\left(\delta_{C} 47.6\right)$ and C-11 $\left(\delta_{C} 34.5\right)$ and ROESY correlations between H-14 $\left(\delta_{\mathrm{H}} 1.98\right.$ and 2.32) and $\mathrm{H}-10\left(\delta_{\mathrm{H}} 2.88\right)$. The relative stereochemistry of 3 was elucidated on the basis of ROESY experiments (Figure 6). The ROESY cross-peaks between H-8/H-29, H-10/H-12, $\mathrm{H}_{\alpha}-11 / \mathrm{H}-14$, $\mathrm{H}_{\alpha}-11 / \mathrm{H}-24, \mathrm{H}_{\alpha}-11 / \mathrm{H}-29, \mathrm{H}-12 / \mathrm{H}-30$ and $\mathrm{H}-2 / \mathrm{H}-30$ suggested that $\mathrm{H}-10, \mathrm{H}-12, \mathrm{Me}(30)$ and the bond between $\mathrm{C}-7$ and $\mathrm{C}-8$ is on the $\beta$-side and $\mathrm{Me}(29), \mathrm{H}-8$, the geranyl group at $\mathrm{C}-10$ and the isoprenyl group at $\mathrm{C}-12$ are on the $\alpha$-side of 3 . A computer-assisted $3 \mathrm{D}$ structure was obtained by using the molecular modeling program CS CHEM 3D Ultra 12.0, with MM2 force-field calculations for energy minimization. The calculated distances between $\mathrm{H}-8 / \mathrm{H}-29(2.768 \AA), \mathrm{H}-10 / \mathrm{H}-12(2.507 \AA), \mathrm{H}_{\alpha}-11 / \mathrm{H}-14$

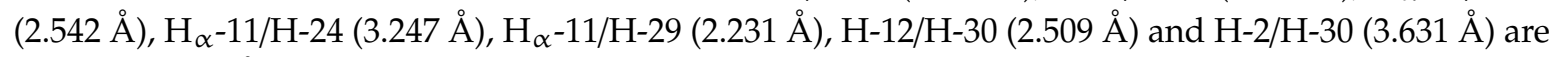
all less than $4 \AA$ (Figure 6); this is consistent with the well-defined ROESY observed for each of the proton pairs. Thus, the structure of 3 was elucidated as shown in Figure 2 and named hypericumone B. This was further confirmed by the ${ }^{1} \mathrm{H}-{ }^{1} \mathrm{H}$ COSY, ROESY, HSQC and HMBC experiments (Figure 7).

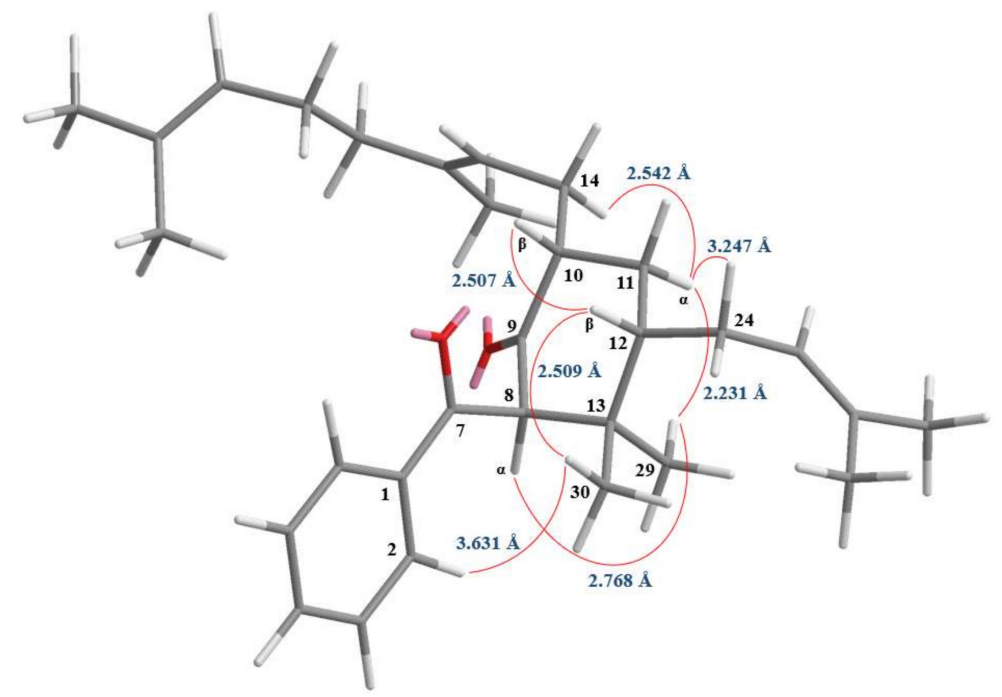

Figure 6. Selected ROESY correlations and relative configuration of 3. 


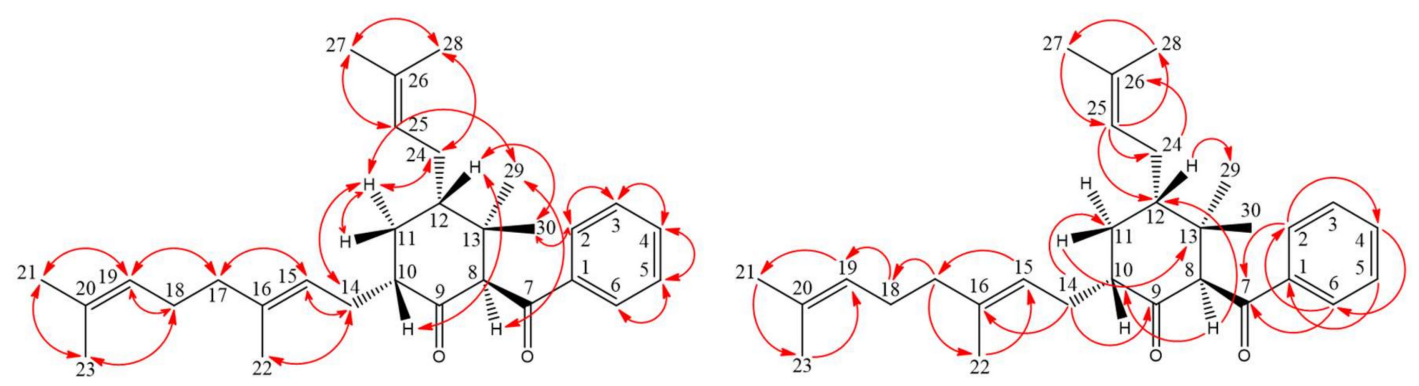

Figure 7. Key NOESY $(\neg)$ and HMBC $(\neg)$ correlations of 3.

\subsection{Structure Identification of the Known Isolates}

The known isolates were readily identified by a comparison of physical and spectroscopic data (UV, IR, ${ }^{1} \mathrm{H}-\mathrm{NMR},[\alpha]_{\mathrm{D}}$ and MS) with corresponding authentic samples or literature values, and this included two xanthones, 1-hydroxy-7-methoxyxanthone (4) [26] and 2-methoxyxanthone (5) [27], two benzophenones, 2,4,6-trihydroxybenzophenone-4-O-geranyl ether (6) [23] and sampsonin B (7) [7], two benzoylphloroglucinol derivatives, sampsonione J (8) [18] and otogirinin A (9) [28].

\subsection{Biological Studies}

2.3.1. Reduction of LPS-Triggered Nitric Oxide (NO) Production in RAW264.7 Cells by Compounds 8 and 9

Nitric oxide (NO) is a mediator in the inflammatory response involved in host defense. The anti-inflammatory effects of the compounds isolated from the aerial parts of $H$. sampsonii were evaluated by suppressing lipopolysaccharide (LPS)-induced NO generation in murine macrophage cell line RAW264.7. The inhibitory activity data of the isolated Compounds 1-9 on NO generation by macrophages are shown in Table 1 . The anti-inflammatory agent, andrographolide (ANDRO), was used as positive control, which was reported to exhibit gastroprotective and ulcer preventive effects, along with its well-documented anti-inflammatory effects [29]. The results of anti-inflammatory assays show that sampsonione J (8) and otogirinin A (9) obviously suppressed NO production comparable with andrographolide, in a concentration-dependent manner in RAW264.7 macrophages (Figure 8A and Table 1). Compounds 8 and 9 are benzoylphloroglucinol derivatives with inhibition (\%) values of $67.20 \pm 3.29$ and $73.10 \pm 1.59 \%$, respectively, against LPS-induced NO production at $50 \mu \mathrm{M}$. Otogirinin A (9) is the most effective among the isolated compounds, with $\mathrm{IC}_{50}=32.87 \pm 1.60 \mu \mathrm{M}$, against LPS-induced NO generation. Both of the Compounds $\mathbf{8}$ and $\mathbf{9}$ did not show significant cytotoxicity against RAW264.7 macrophages (Figure 8B), which suggested that inhibitory activities of Compounds $\mathbf{8}$ and $\mathbf{9}$ on LPS-induced NO production did not resulted from their cytotoxicities. Furthermore, the anti-inflammatory activity of otogirinin A (9) has never been reported previously, thus the detailed mechanism of action of Compound 9 seems to be worth of further studies. 
Table 1. Inhibitory effects of Compounds 1-9 from the aerial parts of $H$. sampsonii on nitric oxide (NO) generation by RAW264.7 murine macrophages in response to lipopolysaccharide (LPS) ${ }^{\text {a }}$.

\begin{tabular}{|c|c|}
\hline Compounds & $\mathrm{IC}_{50}(\mu \mathrm{M})^{\mathrm{b}}$ or $(\operatorname{Inh} \%)^{\mathrm{c}}$ \\
\hline 4-Geranyloxy-2-hydroxy-6-isoprenyloxybenzophenone (1) & $(6.23 \pm 3.71)$ \\
\hline Hypericumone A (2) & $40.32 \pm 2.05^{* *}$ \\
\hline Hypericumone B (3) & $(14.12 \pm 2.19)$ \\
\hline 1-Hydroxy-7-methoxyxanthone (4) ${ }^{d}$ & elicit NO generation \\
\hline 2-Methoxyxanthone (5) d & elicit NO generation \\
\hline 2,4,6-Trihydroxybenzophenone-4-O-geranyl ether (6) & $(23.41 \pm 2.56) *$ \\
\hline Sampsonin B (7) & $(10.48 \pm 3.52)$ \\
\hline Sampsonione J (8) & $35.25 \pm 2.46^{* *}$ \\
\hline Otogirinin A (9) & $32.87 \pm 1.60 * *$ \\
\hline Andrographolide $\mathrm{e}^{\mathrm{a}}$ & $19.36 \pm 1.72 * * *$ \\
\hline
\end{tabular}

${ }^{a}$ Results expressed as average \pm SEM $(n=3)$; ${ }^{b}$ concentration necessary for $50 \%$ inhibition $\left(\mathrm{IC}_{50}\right)$. If $\mathrm{IC}_{50}$ value of compound was $<50 \mu \mathrm{M}$, it is displayed as $\mathrm{IC}_{50}(\mu \mathrm{M})$; ${ }^{\mathrm{c}}$ percentage of inhibition (Inh\%) at $50 \mu \mathrm{M}$. If IC $\mathrm{IC}_{50}$ value of compound was $\geq 50 \mu \mathrm{M}$, it was shown as (Inh\%) at $50 \mu \mathrm{M}$; ${ }^{\mathrm{d}}$ compound 4 and $5(50 \mu \mathrm{M})$ alone elicit NO generation by LPS-induced murine macrophage cell line RAW264.7.; ${ }^{\mathrm{e}}$ andrographolide was used as positive control; ${ }^{*} p<0.05$ compared with the control; $* * p<0.01$ compared with the control; $* * * p<0.001$ compared with the control.
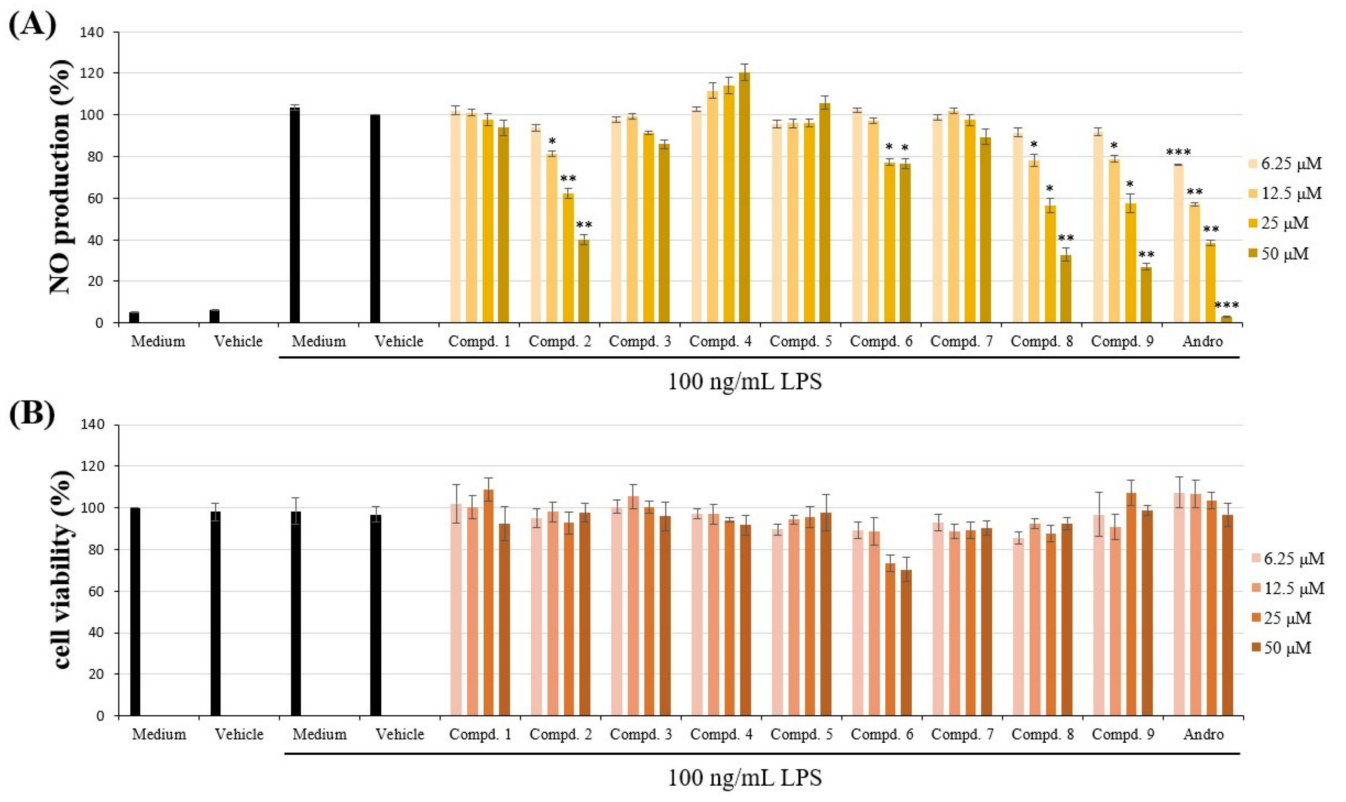

Figure 8. Effects of Compound 1-9 from Hypericum sampsonii on (A) NO production and (B) cytotoxicity in LPS-induced RAW264.7 macrophages. Data expressed as means $\pm \operatorname{SEM}(n=3)$. Asterisks indicate significant differences $\left({ }^{*} p<0.05,{ }^{* *} p<0.01\right.$ and $\left.{ }^{* * *} p<0.001\right)$ from the (media + DMSO + LPS) control group.

\subsubsection{Effect of Otogirinin A (9) on Proinflammatory Mediators in LPS-Stimulated RAW264.7 Cells}

Tumor necrosis factor- $\alpha$ (TNF- $\alpha$ ), interleukin-6 (IL-6), inducible nitric oxide synthase (iNOS) and cyclooxygenase-2 (COX-2) are pivotal proinflammatory mediators during the inflammatory process [30]. We further investigated whether otogirinin A (9) was able to reduce these proinflammatory molecules induced by LPS. The results showed that otogirinin A (9) suppressed LPS-induced TNF- $\alpha$ generation but did not exhibit significant inhibitory activity against IL-6 production (Figure 9A). In addition, the expression level of iNOS was reduced by treatment with otogirinin A (9); however, there was no significant difference of COX-2 by treatment with otogirinin A (9) (Figure 9B). Therefore, otogirinin A (9) exhibited the anti-inflammatory activity by reducing iNOS protein expression instead of COX-2. 
(A)
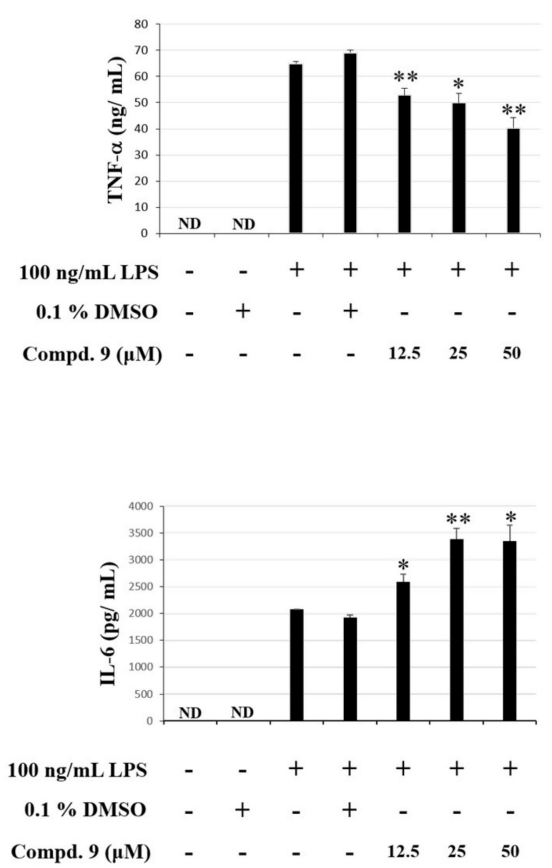

(B)

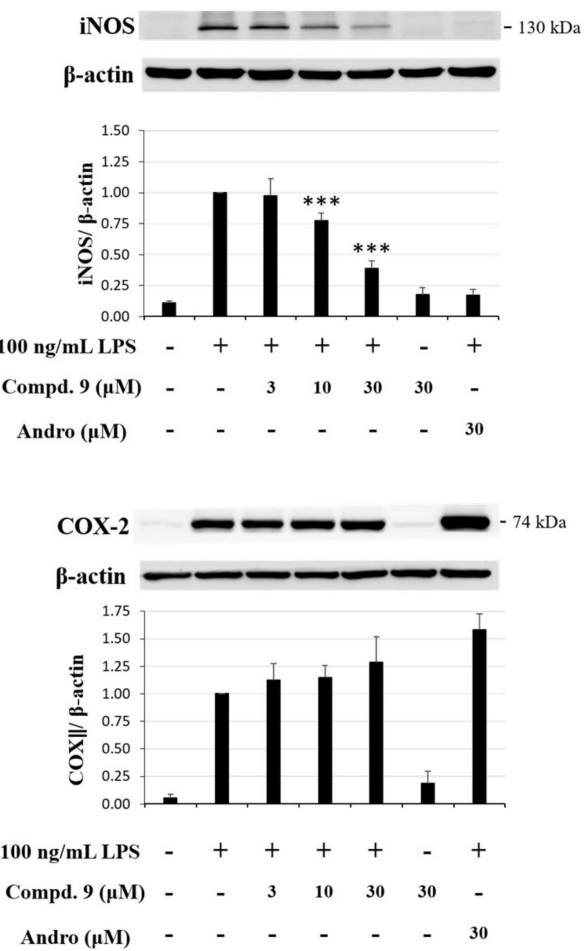

Figure 9. Effect of otogirinin A (9) on proinflammatory mediator expression in LPS-induced RAW264.7 macrophages. (A) Expression levels of TNF- $\alpha$ and IL-6 determined by ELISA. Data expressed as means $\pm \operatorname{SEM}(n=3)$. Asterisks indicate significant differences $\left({ }^{*} p<0.05\right.$ and $\left.{ }^{* *} p<0.01\right)$ from the (media + DMSO + LPS) control group; (B) expression of iNOS and COX2 was determined by Western blot analysis. Data expressed as means $\pm \operatorname{SEM}(n=3)$. Asterisks indicate significant differences $\left(^{* * *} p<0.001\right)$ from the (media + LPS) control group.

\subsubsection{Effect of Otogirinin A (9) on M2 Polarization of Macrophages in LPS-Stimulated RAW264.7 Cells}

M2-polarized macrophages are important on tissue repair [31]. Arginase 1 is an important M2 marker that connects Krüppel-like factor 4 (KLF4) to the biologic processes involved in M2 polarization [32]. High level of arginase-1 can compete with iNOS for arginine and reduce NO production [33]. In addition, KLF4, which is one of the major members of the KLF family, was shown to induce M2 macrophage phenotype, whereas it reduced M1 macrophage expression [34]. We further examined whether otogirinin A (9) enhanced the expression level of M2 macrophages. The result showed that expression levels of arginase- 1 and KLF4 were both induced by treatment with otogirinin A (9) with a concentration-dependent manner (Figure 10A,B). These results suggested that otogirinin A (9) promoted macrophage M2 markers, arginase-1 and KLF4, which exhibited the anti-inflammatory activity.

\subsubsection{Effect of Otogirinin A (9) on MAPK Phosphorylation Pathway in LPS-Stimulated RAW264.7 Cells}

Mitogen-activated protein kinases (MAPKs) are crucial transcription factors for anti-inflammatory therapeutics because their activation and involvement in regulation of the synthesis of inflammation mediators at transcriptional and translational levels [35]. To investigate the MAPK pathway, we examined whether otogirinin A (9) effected on LPS-induced phosphorylation of extracellular signal-regulated kinase (ERK), c-JUN N-terminal kinase (JNK) and p38 MAPKs by Western blot analysis. The result showed that the expression levels of pJNK were dramatically reduced by treatment with otogirinin A (9) (Figure 11A). However, no significant difference of pp38 and pERK was observed when treated with otogirinin A (9) (Figure 11B,C). Therefore, otogirinin A (9) suppressed MAPK/JNK signaling pathway by reducing the phosphorylation of JNK instead of p38 and ERK. 
(A)

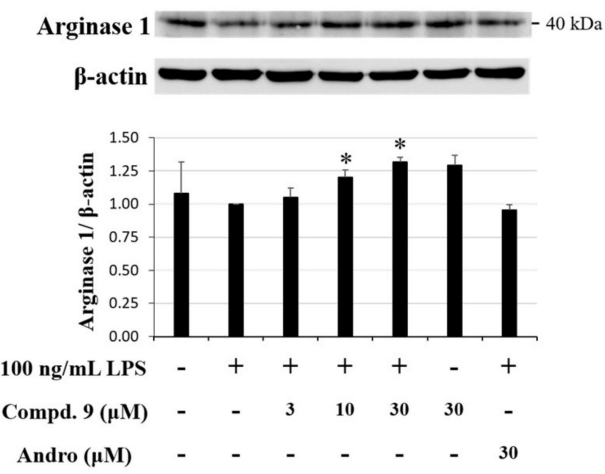

(B)

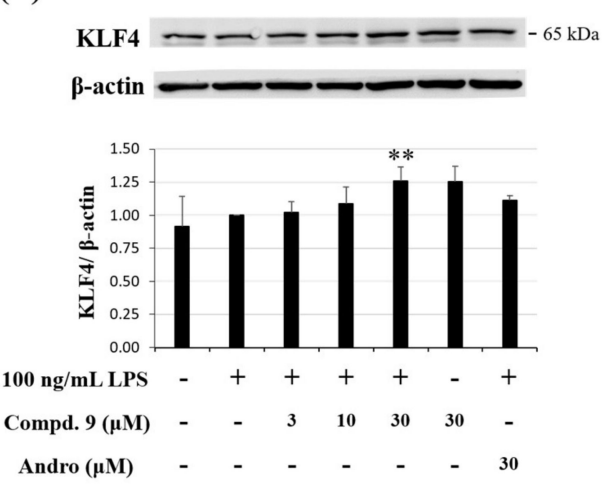

Figure 10. Effect of otogirinin A (9) on M2 polarized macrophages in LPS-stimulated RAW264.7 macrophages. (A,B) Expression of arginase 1 and KLF4 was determined by Western blot analysis. Data expressed as means $\pm \operatorname{SEM}(n=3)$. Asterisks indicate significant differences $\left({ }^{*} p<0.05\right.$ and $\left.{ }^{* *} p<0.01\right)$ from the (media + LPS) control group.

(A)
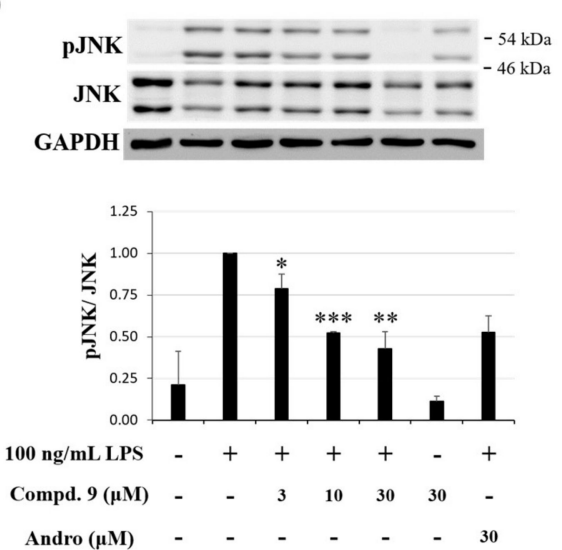

(C)

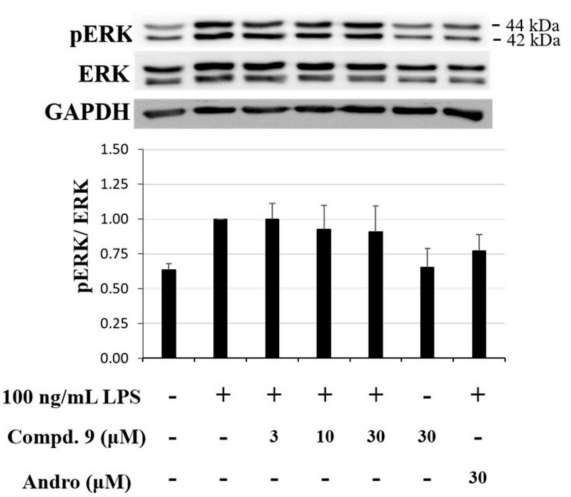

(B)
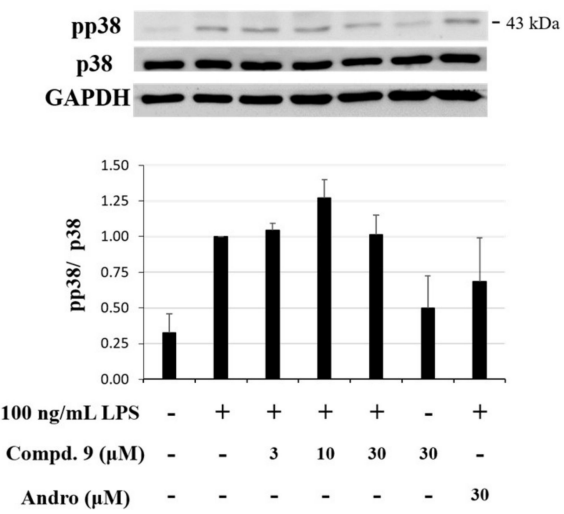

(D)
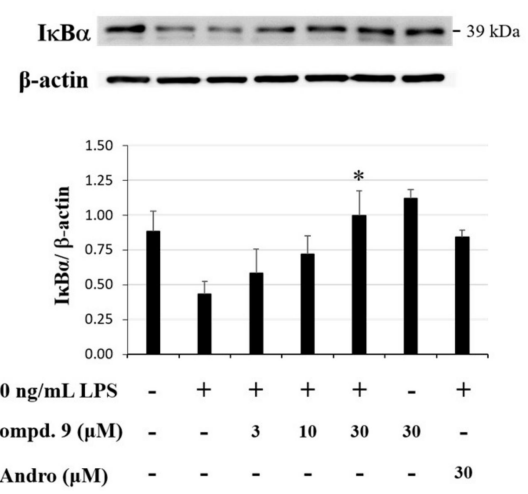

Figure 11. Effect of otogirinin A (9) on the phosphorylation of MAPKs and NF-kB pathways in LPS-stimulated RAW264.7 macrophages. (A-C) Cells pretreated with different concentration of Compound 9 then stimulated with LPS $(100 \mathrm{ng} / \mathrm{mL})$. MAPKs and phosphorylation of MAPKs were detected by Western blot antibodies against p-JNK, JNK, p-p38, p38, p-ERK and ERK; (D) Cells were pretreated with different concentration of Compound 9 then stimulated with LPS $(100 \mathrm{ng} / \mathrm{mL})$. The expression of IKB $\alpha$ was detected by Western blot analysis. Data expressed as means $\pm \operatorname{SEM}(n=3)$. Asterisks indicate significant differences $\left({ }^{*} p<0.05,{ }^{* *} p<0.01\right.$ and $\left.{ }^{* * *} p<0.001\right)$ from the (media + LPS) control group. 


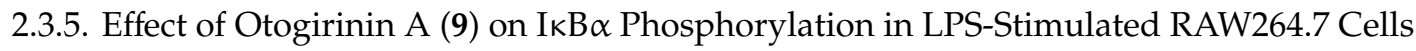

NF- $\mathrm{KB}$ is a potential target in the inflammation process and known to be a molecular target of anti-inflammatory drugs. Upon LPS activation, IкB kinase (IKK) phosphorylates IкB $\alpha$ and triggers ubiquitin-dependent IкB $\alpha$ degradation in the proteasome, resulting in rapid and transient nuclear translocation of NF- $\mathrm{KB}$ [36]. Therefore, we examined if otogirinin A (9) could suppress the degradation of $\mathrm{I} \kappa \mathrm{B} \alpha$ and translocation of NF- $\mathrm{KB}$ into the nucleus. The result indicated that otogirinin A (9) elevated the protein expression of $I \kappa B \alpha$, which attenuated $I \kappa B \alpha$ degradation and thus inhibited the translocation of NF- $\kappa B$ into the nucleus in LPS-stimulated RAW264.7 macrophages (Figure 11D). These results reveal that the suppression of degradation of $I \kappa B \alpha$ by otogirinin $A(9)$ may be involved in the inhibition of LPS-stimulated NF-kB activation in RAW264.7 cells.

\section{Experimental Section}

\subsection{General Procedures}

Optical rotations were measured using a Jasco P-2000 polarimeter (Japan Spectroscopic Corporation, Tokyo, Japan) in $\mathrm{CHCl}_{3}$. Ultraviolet (UV) spectra were obtained on a Hitachi U-2800 Double Beam Spectrophotometer (Hitachi High-Technologies Corporation, Tokyo, Japan). Infrared (IR) spectra (neat or $\mathrm{KBr}$ ) were recorded on a Shimadzu IRAffinity-1S FT-IR spectrophotometer (Shimadzu Corporation, Kyoto, Japan). Nuclear magnetic resonance (NMR) spectra, including correlation spectroscopy (COSY), nuclear Overhauser effect spectrometry (NOESY), rotating frame nuclear Overhauser effect spectrometry (ROESY), heteronuclear multiple-bond correlation (HMBC) and heteronuclear single-quantum coherence (HSQC) experiments, were acquired using a BRUKER AVIII-500 or a BRUKER AVIII-600 spectrometer (Bruker, Bremen, Germany) operating at 500 or $600 \mathrm{MHz}\left({ }^{1} \mathrm{H}\right)$ and 125 or $150 \mathrm{MHz}\left({ }^{13} \mathrm{C}\right)$, respectively, with chemical shifts given in ppm $(\delta)$ using $\mathrm{CDCl}_{3}$ as an internal standard (peak at $7.263 \mathrm{ppm}$ ). HPLC separations were performed utilizing a LC-2000 Plus HPLC system (Jasco, Tokyo, Japan) equipped with PU-2080 Plus pumps and a MD-2010 Plus diode array detector, using ChromNav software (version 2.0, Jasco). Cosmosil 5SL-II (Nacalai Tesque, $5 \mu \mathrm{m}$; columns of dimensions $10 \times 250 \mathrm{~mm}$ ) columns were used for semipreparative HPLC. Electrospray ionization (ESI) and high-resolution electrospray ionization (HRESI)-mass spectra were recorded on a Bruker APEX II mass spectrometer (Bruker, Bremen, Germany) or a (HPLC/MS-MS) VARIAN and VARIAN 901-MS (Varian, Inc., Palo Alto, CA, USA). Silica gel (70-230, 230-400 mesh, Merck) was used for column chromatography (CC). Silica gel 60 F-254 (Merck, Darmstadt, Germany) was used for thin-layer chromatography (TLC) and preparative thin-layer chromatography (PTLC).

\subsection{Plant Material}

The aerial parts of Hypericum sampsonii Hance (Hyperiaceae), bought from Li-Fa pharmaceutical company, were collected from Guangxi, China, in September 2016 and identified by Prof. J.-J. Chen. A voucher specimen (HS-201,609) was deposited in the Faculty of Pharmacy, National Yang-Ming University, Taipei, Taiwan.

\subsection{Extraction and Isolation}

The dried aerial parts $(3.1 \mathrm{~kg})$ of $\mathrm{H}$. sampsonii were extracted three times with $\mathrm{MeOH}(15 \mathrm{~L}$ each) for three days. The extract was concentrated under reduced pressure at $35^{\circ} \mathrm{C}$, and the residue (192.4 g) was partitioned between $n$-hexane and $\mathrm{H}_{2} \mathrm{O}(1: 1)$ to provide the $n$-hexane-soluble fraction (fraction $\mathrm{A} ; 82.1 \mathrm{~g}$ ). The $\mathrm{H}_{2} \mathrm{O}$-soluble fraction was further extracted with $\mathrm{CH}_{2} \mathrm{Cl}_{2}$ and provided $\mathrm{CH}_{2} \mathrm{Cl}_{2}$-soluble part (fraction B; $17.9 \mathrm{~g}$ ). Finally, the $\mathrm{H}_{2} \mathrm{O}$-soluble one was extracted with EtOAc, and the EtOAc-soluble part (fraction $\mathrm{C} ; 16.1 \mathrm{~g}$ ) and the $\mathrm{H}_{2} \mathrm{O}$-soluble one (fraction D; $62.9 \mathrm{~g}$ ) were separated. Fraction A (82.1 g) was purified by CC (4.0 kg of silica gel, 63-200 mesh; $n$-hexane/EtOAc gradient) to afford 11 fractions: A1-A11. Fraction A1 $(1.44 \mathrm{~g})$ was subjected to CC (60 g of silica gel, 230-400 mesh; $n$-hexane/EtOAc 1:0-9:1, 500 mL-fractions) to give 11 subfractions: A1-1-A1-11. Fraction A1-8 
(302 mg) was purified by preparative TLC (silica gel; $n$-hexane/ $\mathrm{CH}_{2} \mathrm{Cl}_{2}$ 3:2) and collected the major part. Then the major part was further purified by preparative TLC (silica gel; $n$-hexane/EtOAc 9:1) to obtain 1-hydroxy-7-methoxyxanthone (4) (8.5 mg) and sampsonin B (7) (2.7 mg). Fraction A2 (5.88 g) was subjected to CC (250 g of silica gel, 230-400 mesh; $n$-hexane/EtOAc 1:0-9:1, 500 mL-fractions) to give 10 subfractions: A2-1-A2-10. Part (117 mg) of fraction A2-1 was purified by preparative TLC (silica gel; $n$-hexane/a etone 19:1) and collected the major part. Then the major part was further purified by silica HPLC (Cosmosil 5SL-II column, $10 \times 250 \mathrm{~mm}$ ) with $n$-hexane/ $\mathrm{CH}_{2} \mathrm{Cl}_{2}(4: 6,2.0 \mathrm{~mL} / \mathrm{min})$ to yield hypericumone A (2) (2.5 mg, eluted at $11.25 \mathrm{~min}$ ). Part (133 mg) of fraction A2-4 was further purified by preparative TLC (silica gel; $n$-hexane/ $\mathrm{CH}_{2} \mathrm{Cl}_{2} 4: 6$ ) to afford 2-methoxyxanthone (5) (3.1 mg). Part (122 mg) of fraction A2-8 was further purified by preparative TLC (silica gel; $n$-hexane/ $\mathrm{CH}_{2} \mathrm{Cl}_{2} 1: 1$ ) to afford otogirinin A (9) (9.3 mg). Fraction A3 (5.96 g) was subjected to CC (250 g of silica gel, 230-400 mesh; n-hexane/EtOAc 1:0-9:1, $500 \mathrm{~mL}$-fractions) to give 10 subfractions: A3-1-A3-10. Part (115 mg) of fraction A3-2 was purified by preparative TLC (silica gel; $n$-hexane/ $\mathrm{CH}_{2} \mathrm{Cl}_{2}$ 3:7) and collected the major part. Then the major part was further purified by preparative TLC again (silica gel; $n$-hexane/EtOAc 6:1) to obtain sampsonione J (8) (1.2 mg). Part (129 mg) of Fraction A3-4 was further purified by preparative TLC (silica gel; $n$-hexane/EtOAc 6:1) to afford 4-geranyloxy-2-hydroxy-6-isoprenyloxybenzophenone (1) (4.8 mg). Fraction A5 (1.75 g) was subjected to CC (80 g of silica gel, 230-400 mesh; $n$-hexane/EtOAc 1:0-9:1, $500 \mathrm{~mL}$-fractions) to give 8 subfractions: A5-1-A5-8. Part (131 mg) of fraction A5-4 was purified by preparative TLC (silica gel; $n$-hexane/ $\mathrm{CH}_{2} \mathrm{Cl}_{2}$ 1:1) and collected the major part. Then the major part was purified by silica HPLC (Cosmosil 5SL-II column, $10 \times 250 \mathrm{~mm}$ ) with $n$-hexane/ $\mathrm{CH}_{2} \mathrm{Cl}_{2}$ $(7: 3,2.0 \mathrm{~mL} / \mathrm{min})$ to yield hyperhexanone C (3) $(2.3 \mathrm{mg}$, eluted at $22.33 \mathrm{~min})$. Fraction A6 (2.61 g) was subjected to CC (150 g of silica gel, 230-400 mesh; $n$-hexane/EtOAc 1:0-9:1, 500 mL-fractions) to give 10 subfractions: A6-1-A6-10. Part (117 mg) of fraction A6-2 was further purified by preparative TLC (silica gel; $n$-hexane/ $\mathrm{CH}_{2} \mathrm{Cl}_{2} 3: 7$ ) to afford 2,4,6-trihydroxybenzophenone-4-O-geranyl ether (6) (7.2 mg).

4-Geranyloxy-2-hydroxy-6-isoprenyloxybenzophenone (1): Yellowish oil; UV (MeOH): $\lambda_{\max }$ $(\log \varepsilon)=304(4.12) \mathrm{nm}$; IR: $v_{\max }=3428(\mathrm{OH}), 2922,1618(\mathrm{C}=\mathrm{O}), 1578,1323,1279,1211,1152$, $1099 \mathrm{~cm}^{-1} ;{ }^{1} \mathrm{H}-\mathrm{NMR}$ spectroscopic data, see Table $2 ;{ }^{13} \mathrm{C}-\mathrm{NMR}$ spectroscopic data, see Table 3; HR-ESI-MS: $m / z=433.2370$ [M - H] $]^{-}$(calcd for $\mathrm{C}_{28} \mathrm{H}_{33} \mathrm{O}_{4}, 433.2379$ ); HR-MS, 1D-, and 2D-NMR spectra, see Supplementary Figures S1-S7.

Hypericumone A (2): white amorphous powder; $[\alpha]_{\mathrm{D}}^{25}=-43.5^{\circ}\left(c 0.16, \mathrm{CHCl}_{3}\right) ; \mathrm{UV}(\mathrm{MeOH}): \lambda_{\max }$ $(\log \varepsilon)=249(4.15) \mathrm{nm}$; IR: $v_{\max }=3495(\mathrm{OH}), 2926,1722(\mathrm{C}=\mathrm{O}), 1684(\mathrm{C}=\mathrm{O}), 1446,1259,1109 \mathrm{~cm}^{-1}$; ${ }^{1} \mathrm{H}-\mathrm{NMR}$ spectroscopic data, see Table $2 ;{ }^{13} \mathrm{C}-\mathrm{NMR}$ spectroscopic data, see Table 3; HR-ESI-MS: $m / z=511.2824[\mathrm{M}+\mathrm{Na}]^{+}$(calcd for $\left.\mathrm{C}_{32} \mathrm{H}_{40} \mathrm{O}_{4} \mathrm{Na}, 511.2824\right) ; \mathrm{HR}-\mathrm{MS}, 1 \mathrm{D}-$, and 2D-NMR spectra, see Supplementary Figures S8-S14.

Hypericumone B (3): colorless oil; $[\alpha]_{\mathrm{D}}^{25}=+326.4^{\circ}\left(c 0.15, \mathrm{CHCl}_{3}\right) ; \mathrm{UV}(\mathrm{MeOH}): \lambda_{\max }(\log \varepsilon)=249$ $(4.10) \mathrm{nm} ; \mathrm{IR}: v_{\max }=1707(\mathrm{C}=\mathrm{O}), 1672(\mathrm{C}=\mathrm{O}), 1446,1211,1184,1080 \mathrm{~cm}^{-1},{ }^{1} \mathrm{H}-\mathrm{NMR}$ spectroscopic data, see Table $2 ;{ }^{13} \mathrm{C}-\mathrm{NMR}$ spectroscopic data, see Table 3; HR-ESI-MS: $m / z=457.3086[\mathrm{M}+\mathrm{Na}]^{+}$(calcd for $\mathrm{C}_{30} \mathrm{H}_{42} \mathrm{O}_{2} \mathrm{Na}$, 457.3083); HR-MS, 1D-, and 2D-NMR spectra, see Supplementary Figures S15-S21. 
Table 2. ${ }^{1} \mathrm{H}-\mathrm{NMR}$ data for Compounds $1-3$ ( $\delta$ in ppm, $J$ in $\left.\mathrm{Hz}\right)$.

\begin{tabular}{|c|c|c|c|}
\hline Position & $1^{a}$ & $2^{b}$ & $3^{b}$ \\
\hline \multicolumn{4}{|l|}{1} \\
\hline 2 & & & 7.99 br d (7.5) \\
\hline 3 & \multirow[t]{2}{*}{$6.16 \mathrm{~d}(2.5)$} & & 7.45 br t (7.5) \\
\hline 4 & & & 7.55 br t (7.5) \\
\hline 5 & $5.93 \mathrm{~d}(2.5)$ & & 7.45 br t $(7.5)$ \\
\hline 6 & & $\begin{array}{l}2.08 \mathrm{dd}(13.8,4.1) \\
2.32 \mathrm{dd}(13.8,2.0)\end{array}$ & 7.99 br d (7.5) \\
\hline 7 & & $1.80 \mathrm{~m}$ & \\
\hline \multicolumn{2}{|l|}{8} & & \multirow[t]{2}{*}{$4.35 \mathrm{~s}$} \\
\hline 9 & $7.48 \mathrm{~d}(7.5)$ & & \\
\hline 10 & 7.35 br t $(7.5)$ & & $2.88 \mathrm{~m}$ \\
\hline 11 & \multicolumn{2}{|l|}{7.43 br t $(7.5)$} & $\begin{array}{l}1.14 \mathrm{~m} \\
2.20 \mathrm{~m}\end{array}$ \\
\hline 12 & 7.35 br t (7.5) & 7.56 br d (8.4) & $2.64 \mathrm{~m}$ \\
\hline 13 & $7.48 \mathrm{~d}(7.5)$ & 7.33 br dd $(8.4,7.4)$ & \\
\hline \multicolumn{2}{|l|}{14} & 7.45 br t $(7.4)$ & $\begin{array}{l}1.98 \mathrm{~m} \\
2.32 \mathrm{~m}\end{array}$ \\
\hline \multicolumn{2}{|l|}{15} & 7.33 br dd $(8.4,7.4)$ & 5.05 br t (7.6) \\
\hline \multicolumn{2}{|l|}{16} & 7.56 br d (8.4) & \\
\hline \multicolumn{2}{|l|}{17} & $1.36 \mathrm{~s}$ & $1.95 \mathrm{~m}$ \\
\hline \multicolumn{2}{|l|}{18} & $1.44 \mathrm{~s}$ & $2.02 \mathrm{~m}$ \\
\hline \multicolumn{2}{|l|}{19} & $1.93 \mathrm{~m}$ & 5.07 br t (6.8) \\
\hline \multicolumn{2}{|l|}{20} & 2.80 br t (10.0) & \\
\hline \multicolumn{2}{|l|}{21} & & $1.66 \mathrm{~s}$ \\
\hline \multicolumn{2}{|l|}{22} & $1.85 \mathrm{~s}$ & $1.58 \mathrm{~s}$ \\
\hline \multicolumn{2}{|l|}{23} & $\begin{array}{l}5.01 \mathrm{br} \mathrm{s} \\
5.25 \mathrm{br} \mathrm{s}\end{array}$ & $1.59 \mathrm{~s}$ \\
\hline 24 & & & $\begin{array}{l}1.67 \mathrm{~m} \\
2.15 \mathrm{~m}\end{array}$ \\
\hline 25 & & & $5.21 \mathrm{brt}(7.4)$ \\
\hline 26 & & & \\
\hline 27 & & & $1.73 \mathrm{~s}$ \\
\hline 28 & & & $1.60 \mathrm{~s}$ \\
\hline 29 & & $2.58 \mathrm{~m}$ & $0.91 \mathrm{~s}$ \\
\hline 30 & & 5.40 br t (7.5) & $0.99 \mathrm{~s}$ \\
\hline 31 & & & \\
\hline 32 & & $1.69 \mathrm{~s}$ & \\
\hline 33 & & $2.11 \mathrm{~m}$ & \\
\hline 34 & & $2.14 \mathrm{~m}$ & \\
\hline 35 & & 5.10 br t (6.7) & \\
\hline 36 & & & \\
\hline 37 & & $1.62 \mathrm{~s}$ & \\
\hline 38 & & $1.68 \mathrm{~s}$ & \\
\hline $1^{\prime}$ & $4.58 \mathrm{~d}(6.5)$ & & \\
\hline $2^{\prime}$ & 5.48 br t $(6.5)$ & & \\
\hline $3^{\prime}$ & & & \\
\hline $4^{\prime}$ & 2.11 br t (6.5) & & \\
\hline $5^{\prime}$ & $2.14 \mathrm{~m}$ & & \\
\hline $6^{\prime}$ & 5.10 br t (6.5) & & \\
\hline $7^{\prime}$ & & & \\
\hline $8^{\prime}$ & $1.69 \mathrm{~s}$ & & \\
\hline $9^{\prime}$ & $1.76 \mathrm{~s}$ & & \\
\hline $10^{\prime}$ & $1.62 \mathrm{~s}$ & & \\
\hline $1^{\prime \prime}$ & $4.18 \mathrm{~d}(6.0)$ & & \\
\hline $2^{\prime \prime}$ & 4.62 br t $(6.0)$ & & \\
\hline $3^{\prime \prime}$ & & & \\
\hline $4^{\prime \prime}$ & $1.57 \mathrm{~s}$ & & \\
\hline $5^{\prime \prime}$ & $1.50 \mathrm{~s}$ & & \\
\hline $2-\mathrm{OH}$ & $12.37 \mathrm{~s}$ & & \\
\hline 3-OH & & $3.38 \mathrm{~s}$ & \\
\hline
\end{tabular}


Table 3. ${ }^{13} \mathrm{C}-\mathrm{NMR}$ data for Compounds $\mathbf{1}-\mathbf{3}$ ( $\delta$ in ppm).

\begin{tabular}{|c|c|c|c|}
\hline Position & $1^{a}$ & $2^{a}$ & $3^{a}$ \\
\hline 1 & 105.7 & 80.6 & 138.5 \\
\hline 2 & 166.1 & 211.6 & 128.7 \\
\hline 3 & 94.1 & 82.6 & 128.6 \\
\hline 4 & 165.8 & & 133.2 \\
\hline 5 & 92.5 & 58.6 & 128.6 \\
\hline 6 & 161.4 & 36.1 & 128.7 \\
\hline 7 & 199.6 & 42.0 & 196.7 \\
\hline 8 & 142.3 & 50.8 & 72.1 \\
\hline 9 & 127.4 & 212.3 & 208.4 \\
\hline 10 & 127.5 & 193.3 & 47.6 \\
\hline 11 & 130.2 & 134.5 & 34.5 \\
\hline 12 & 127.5 & 129.1 & 40.3 \\
\hline 13 & 127.4 & 128.1 & 43.3 \\
\hline 14 & & 132.8 & 27.4 \\
\hline 15 & & 128.1 & 121.6 \\
\hline 16 & & 129.1 & 136.7 \\
\hline 17 & & 21.7 & 39.8 \\
\hline 18 & & 24.5 & 26.8 \\
\hline 19 & & 26.0 & 124.3 \\
\hline 20 & & 41.6 & 131.3 \\
\hline 21 & & 142.5 & 25.7 \\
\hline 22 & & 21.7 & 16.2 \\
\hline 23 & & 118.5 & 17.7 \\
\hline 24 & & & 28.1 \\
\hline 25 & & & 123.6 \\
\hline 26 & & & 132.4 \\
\hline 27 & & & 25.8 \\
\hline 28 & & & 17.8 \\
\hline 29 & & 26.3 & 22.1 \\
\hline 30 & & 118.5 & 26.1 \\
\hline 31 & & 139.0 & \\
\hline 32 & & 16.2 & \\
\hline 33 & & 40.2 & \\
\hline 34 & & 26.4 & \\
\hline 35 & & 124.1 & \\
\hline 36 & & 131.7 & \\
\hline 37 & & 17.7 & \\
\hline 38 & & 25.8 & \\
\hline $1^{\prime}$ & 65.2 & & \\
\hline $2^{\prime}$ & 118.4 & & \\
\hline $3^{\prime}$ & 142.3 & & \\
\hline $4^{\prime}$ & 39.5 & & \\
\hline $5^{\prime}$ & 26.3 & & \\
\hline $6^{\prime}$ & 123.6 & & \\
\hline $7^{\prime}$ & 131.9 & & \\
\hline $8^{\prime}$ & 25.7 & & \\
\hline $9^{\prime}$ & 16.7 & & \\
\hline $10^{\prime}$ & 17.7 & & \\
\hline $1^{\prime \prime}$ & 65.1 & & \\
\hline $2^{\prime \prime}$ & 118.4 & & \\
\hline $3^{\prime \prime}$ & 137.0. & & \\
\hline $4^{\prime \prime}$ & 25.5 & & \\
\hline $5^{\prime \prime}$ & 18.0 & & \\
\hline
\end{tabular}




\subsection{Biologic Assay}

The effect of the isolated compounds on macrophage proinflammatory response was evaluated by monitoring the inhibition of nitric oxide (NO), iNOS, TNF- $\alpha$ and IL-6 generation. The purity of the tested compounds was $>98 \%$ as identified by NMR and MS.

\subsubsection{Chemicals and Antibodies}

Andrographolide (ANDRO), LPS and bovine serum albumin (BSA) were purchased from Sigma-Aldrich (St. Louis, MO, USA). The antibodies against iNOS, IкB- $\alpha$, ERK, phospho-ERK (Thr202/Thr204), JNK, phospho-JNK (Thr183/Tyr185), p38, phospho-p38 (Thr180/Tyr182), KLF4, arginase 1 and glyceraldehyde-3-phosphate dehydrogenase (GAPDH) were purchased from Cell Signaling Technology (Danvers, MA, USA). Anti-COX-2 antibody was purchased from Arigo (Hsinchu, Taiwan). Anti- $\beta$-actin antibody was purchased from Sigma-Aldrich.

\subsubsection{Cells and Culture Medium}

Preparation of RAW264.7 murine macrophages were carried out in accord with methods discussed in the literatures [37]. The murine macrophage cell line RAW264.7 was cultures in DMEM supplemented with $10 \%$ heat-inactivated fetal bovine serum (FBS), $100 \mathrm{U} / \mathrm{mL}$ penicillin and $100 \mu \mathrm{g} / \mathrm{mL}$ streptomycin. Cells were incubated at $37^{\circ} \mathrm{C}$ humidified $5 \% \mathrm{CO}_{2}$ atmosphere in a fully humid atmosphere.

\subsubsection{Determination of NO Production}

The murine macrophage cell line RAW264.7 (4 × $10^{5}$ cells in 96-well plates) was cultured in DMEM supplemented with $10 \%$ heat-inactivated fetal bovine serum (FBS) and incubated at $37^{\circ} \mathrm{C}$ humidified 5\% $\mathrm{CO}_{2}$ atmosphere with a 96-well flat-bottomed culture plate. After $24 \mathrm{~h}$, RAW264.7 cells were pretreated with Compounds 1-9 $(0,6.25,12.5,25$ and $50 \mu \mathrm{M})$ or vehicle $(0.1 \%$ DMSO) for $1 \mathrm{~h}$, respectively and incubated in the presence of LPS (100 ng/mL) under the same condition for $20 \mathrm{~h}$. The cultured cells were then centrifuged and the supernatants were used for NO-production measurement. The supernatant was mixed with an equal volume of the Griess reagent (1\% sulfanilamide, $0.1 \% \mathrm{~N}$-(naphthalen-1-yl)ethylenediamine dihydrochloride in $2.5 \% \mathrm{H}_{2} \mathrm{PO}_{4}$ soln.) and incubated for $15 \mathrm{~min}$ at room temperature. Nitrite concentration was determined by measuring the absorbance at $550 \mathrm{~nm}$ using an ELISA plate reader ( $\mu$ Quant) [38].

\subsubsection{MTT Assay}

A MTT colorimetric assay was used to determine cell viability. The assay was modified from that of Mosmann [39]. MTT reagent $(0.5 \mathrm{mg} / \mathrm{mL})$ was added onto the attached cells mentioned above (100 $\mathrm{L}$ per $100 \mu \mathrm{L}$ culture) and incubated at $37^{\circ} \mathrm{C}$ for $3 \mathrm{~h}$. Then, DMSO was added and amount of colored formazan metabolite formed was measured by absorbance at $570 \mathrm{~nm}$ using an ELISA plate reader ( $\mu$ Quant). The optical density of formazan formed in control (untreated) cells was taken as $100 \%$ viability.

\subsubsection{Enzyme-Linked Immunosorbent Assay}

RAW264.7 cells ( $4 \times 10^{5}$ cells in 96-well plates) were pretreated with Compound 9 or vehicle (0.1\% DMSO) for $1 \mathrm{~h}$ and then incubated with LPS (100 ng/mL) for $20 \mathrm{~h}$. Supernatants were collected and analyzed for production of TNF- $\alpha$ and IL- 6 by using appropriate ELISA kits (R\&D, MN, USA) in accordance with the manufacturer's instructions.

\subsubsection{Western Blotting}

Western blot analysis followed as previously described with slight changes [40]. Then, $1.0 \times 10^{6}$ cells were seeded into $6 \mathrm{~cm}$ dish and grown until 80-85\% confluent. Compound 9 and LPS (100 ng/mL) were added or were not added. After 15 min (for detecting p-IkB, p-ERK, p-JNK and 
p-p38) and $24 \mathrm{~h}$ (for detecting iNOS, COX-2, arginase 1 and KLF4) of incubation at $37^{\circ} \mathrm{C}$, cultured medium was removed, and cells were washed with ice-cold PBS. After RIPA buffer (Cell Signaling, MA, USA) was added, cells were scraped off the plate and transferred to the Eppendorf on ice immediately. The proteins were quantified using the BCA protein assay. Cells were preserved at $-80^{\circ} \mathrm{C}$ overnight and then centrifuged $\left(15,000 \times \mathrm{rpm}, 30 \mathrm{~min}, 4^{\circ} \mathrm{C}\right)$. Equal amount of protein samples $(25 \mu \mathrm{g})$ and pre-stained protein marker were loaded onto SDS-PAGE. After being stacked at $80 \mathrm{~V}$ and separated at $100 \mathrm{~V}$, the proteins were transferred onto the polyvinylidene fluoride (PVDF) membranes at $350 \mathrm{~mA}$. The PVDF membranes were blocked with $5 \%(w / v)$ of BSA with Tris-buffered saline (TBST) containing $0.1 \%(v / v)$ Tween-20 at room temperature for $1 \mathrm{~h}$ and washed three times with TBST for 15 min each time. Primary antibodies were incubated with the membranes overnight, shaking at $4{ }^{\circ} \mathrm{C}$. Then each membrane was washed with TBST and incubated with horseradish peroxidase (HRP)-conjugated secondary antibodies at room temperature for $1 \mathrm{~h}$ while shaking. Finally, each membrane was developed using ECL detection kit, and the images were visualized by ImageQuant LAS 4000 mini (GE Healthcare, MA, USA). Band densities were quantified using ImageJ software (BioTechniques, NY, USA).

\subsubsection{Statistical Analysis}

All data are expressed as mean \pm SEM Statistical analysis was carried out using Student's $t$-test. A probability of 0.05 or less was considered statistically significant. Microsoft Excel 2010 was used for the statistical and graphic evaluation. All the experiments were performed at least three times.

\section{Conclusions}

Nine isolates, including three new compounds, 4-geranyloxy-2-hydroxy-6-isoprenyl-oxybenzophenone (1), hypericumone A (2) and hypericumone B (3), were isolated from the aerial parts of H. sampsonii. Structures of these compounds were established by spectroscopic data. Hypericumone A (2), sampsonione J (8) and otogirinin A (9) exhibited potent inhibition $\left(\mathrm{IC}_{50}\right.$ values $\left.\leq 40.32 \mu \mathrm{M}\right)$ against LPS-induced nitric oxide (NO) generation. Otogirinin A (9) was the most effective among the isolated compounds, with $\mathrm{IC}_{50}$ value of $32.87 \pm 1.60 \mu \mathrm{M}$, against LPS-induced NO generation. Our results demonstrated that otogirinin A (9) suppressed LPS-induced iNOS expression and NO and TNF- $\alpha$ generation via blocking the phosphorylation of MAPK/JNK and degradation of IKB $\alpha$, whereas it showed no effect on the phosphorylation of MAPKs/ERK and p38. In addition, otogirinin A (9) stimulated anti-inflammatory M2 phenotype by elevating the expression of arginase 1 and KLF4. In conclusion, otogirinin A (9) interfered with multiple intracellular targets. We can also draw a schematic diagram that how otogirinin A (9) influenced the polarization of M1 and M2 macrophages (Figure 12). The above results suggested that $H$. sampsonii and its isolates (especially 2, 8 and 9) are worth further research and may be expectantly developed as candidates for the treatment or prevention of various inflammatory diseases. 


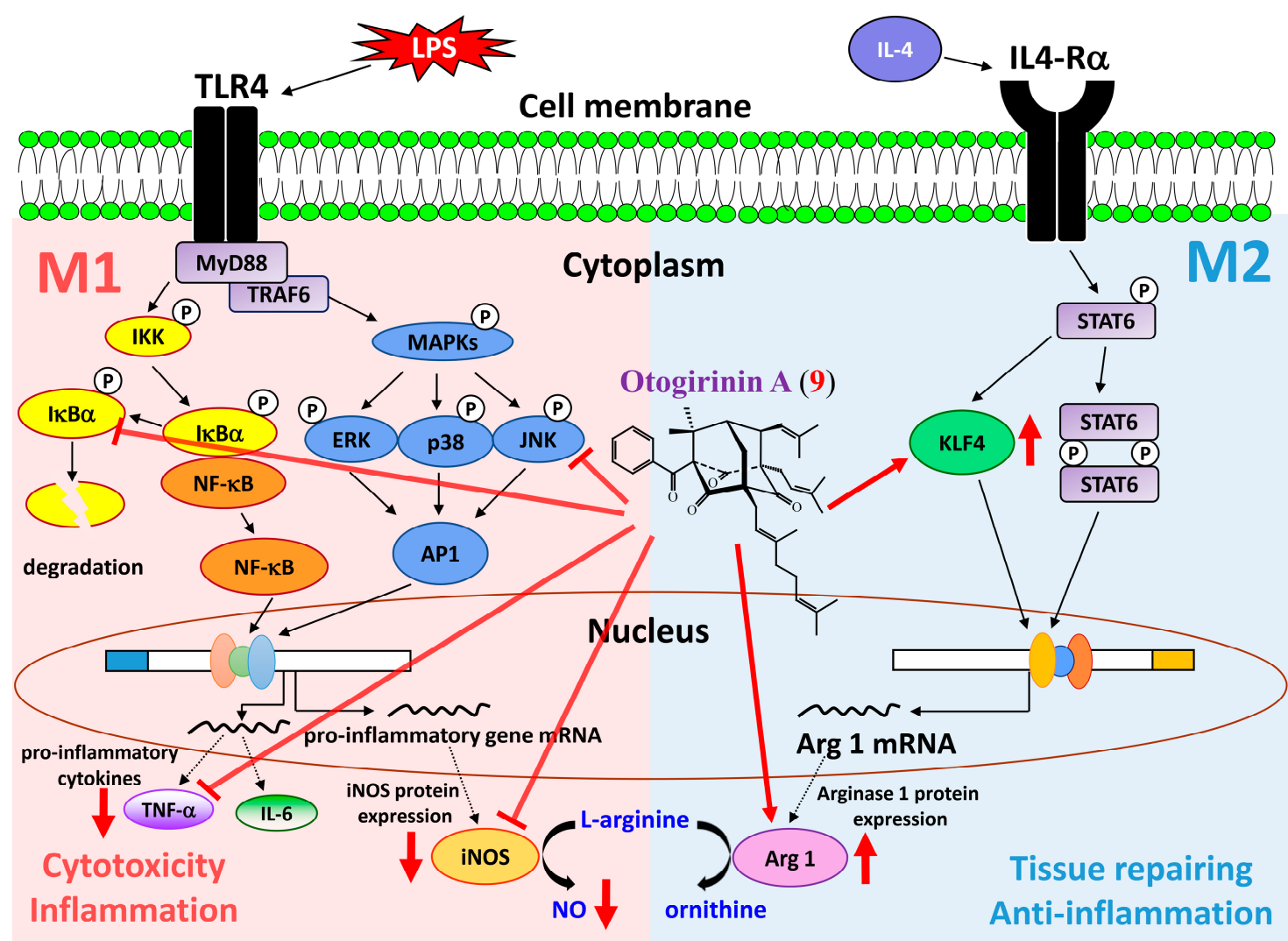

Figure 12. Schematic diagram for anti-inflammatory action of otogirinin A (9) in LPS-induced RAW264.7 macrophages.

Supplementary Materials: Supplementary Materials are available online, Figures S1-S7: HR-MS, 1D and 2D-NMR spectra for 4-geranyloxy-2-hydroxy-6-isoprenyloxybenzophenone (1), Figures S8-S14: HR-MS, 1D and 2D-NMR spectra for hypericumone A (2), Figures S15-S21: HR-MS, 1D and 2D-NMR spectra for hypericumone B (3).

Author Contributions: C.-Y.H. and T.-C.C. performed the isolation and structure elucidation of the constituents and manuscript writing. Y.-J.W. and Y.C. conducted the bioassay and analyzed the data. J.-J.C. planned, designed and organized all of the research of this study and the preparation of the manuscript. All authors have read and agreed to the published version of the manuscript.

Funding: This research was supported by grants from the Ministry of Science and Technology (MOST), Taiwan (No. MOST 106-2320-B-010-033-MY3 and MOST 109-2320-B-010-029-MY3), awarded to J.-J.C.

Conflicts of Interest: The authors declare no conflict of interest.

\section{References}

1. Lin, Y.L.; Wu, Y.S. Polyprenylated phloroglucinol derivatives from Hypericum sampsonii. Helv. Chim. Acta 2003, 86, 2156-2163. [CrossRef]

2. Chiu, N.Y.; Chang, K.H. The Illustrated Medicinal Plants of Taiwan; SMC Pubishing Inc.: Taipei, Taiwan, 1986; Volume 2, p. 126.

3. Hong, D.; Yin, F.; Hu, L.H.; Lu, P. Sulfonated xanthones from Hypericum sampsonii. Phytochemistry 2004, 65, 2595-2598. [CrossRef]

4. Xiao, Z.Y.; Shiu, W.K.P.; Zeng, Y.H.; Mu, Q.; Gibbons, S. A naturally occurring inhibitory agent from Hypericum sampsonii with activity against multidrug-resistant Staphylococcus aureus. Pharma. Biol. 2008, 46, 250-253. [CrossRef]

5. Xin, W.B.; Mao, Z.J.; Jin, G.L.; Qin, L.P. Two new xanthones from Hypericum sampsonii and biological activity of the isolated compounds. Phytother. Res. 2011, 25, 536-539. [CrossRef] 
6. Zhu, H.; Chen, C.; Yang, J.; Li, D.; Zhang, J.; Guo, Y.; Wang, J.; Luo, Z.; Xue, Y.; Zhang, Y. Hyperhexanone A, a crucial intermediate from bicyclo[3.3.1]- to cyclohexanone monocyclic-polycyclic polyprenylated acylphloroglucinols. Tetrahedron 2016, 72, 4655-4659.

7. Tian, W.J.; Qiu, Y.Q.; Chen, H.F.; Jin, X.J.; Yao, X.J.; Dai, Y.; Yao, X.S. Chiral separation and absolute configurations of two pairs of racemic polyprenylated benzophenones from Hypericum sampsonii. Fitoterapia 2017, 116, 39-44. [CrossRef] [PubMed]

8. Xiao, Z.Y.; Zeng, Y.H.; Mu, Q.; Shiu, W.K.P.; Gibbons, S. Prenylated benzophenone peroxide derivatives from Hypericum sampsonii. Chem. Biodivers. 2010, 7, 953-958. [CrossRef]

9. Don, M.J.; Huang, Y.J.; Huang, R.L.; Lin, Y.L. New Phenolic Principles from Hypericum sampsonii. Chem. Pharm. Bull. 2004, 52, 866-869. [CrossRef]

10. Chen, Q.; Di, L.; Zhang, Y.; Li, N. Chemical constituents with cytotoxic and anti-inflammatoty activity in Hypericum sampsonii and the antitumor potential under the view of cancer-related inflammation. J. Ethnopharmacol. 2020, 259, 112948. [CrossRef]

11. Xiao, Z.Y.; Mu, Q.; Shiu, W.K.P.; Zeng, Y.H.; Gibbons, S. Polyisoprenylated benzoylphloroglucinol derivatives from Hypericum sampsonii. J. Nat. Prod. 2007, 70, 1779-1782. [CrossRef]

12. Zeng, Y.H.; Osman, K.; Xiao, Z.Y.; Gibbons, S.; Mu, Q. Four geranyl-bearing polyisoprenylated benzoylphloroglucinol derivatives from Hypericum sampsonii. Phytochem. Lett. 2012, 5, 200-205. [CrossRef]

13. Zhu, H.; Chen, C.; Yang, J.; Li, X.N.; Liu, J.; Sun, B.; Huang, S.X.; Li, D.; Yao, G.; Luo, Z.; et al. Bioactive acylphloroglucinols with adamantyl skeleton from Hypericum sampsonii. Org. Lett. 2014, 16, 6322-6325. [CrossRef]

14. Zhu, H.; Chen, C.; Tong, Q.; Chen, X.; Yang, J.; Liu, J.; Sun, B.; Wang, J.; Yao, G.; Luo, Z.; et al. Hyperisampsins H-M, cytotoxic polycyclic polyprenylated acylphloroglucinols from Hypericum sampsonii. Sci. Rep. 2015, 5, 14772. [CrossRef] [PubMed]

15. Zhu, H.C.; Chen, C.M.; Zhang, J.W.; Guo, Y.; Tan, D.D.; Wei, G.Z.; Yang, J.; Wang, J.P.; Luo, Z.W.; Xue, Y.B.; et al. Hyperisampsins $\mathrm{N}$ and $\mathrm{O}$, two new benzoylated phloroglucinol derivatives from Hypericum sampsonii. Chin. Chem. Lett. 2017, 28, 986-990. [CrossRef]

16. Killeen, M.J.; Linder, M.; Pontoniere, P.; Crea, R. NF-кB signaling and chronic inflammatory diseases: Exploring the potential of natural products to drive new therapeutic opportunities. Drug Discov. Today 2014, 19, 373-378. [CrossRef] [PubMed]

17. Karin, M.; Clevers, H. Reparative inflammation takes charge of tissue regeneration. Nature 2016, 529, 307-315. [CrossRef]

18. Hu, L.H.; Sim, K.Y. Cytotoxic polyprenylated benzoylphloroglucinol derivatives with an unusual adamantyl skeleton from Hypericum sampsonii (Guttiferae). Org. Lett. 1999, 1, 879-882. [CrossRef]

19. Ting, C.W.; Hwang, T.L.; Chen, I.S.; Cheng, M.J.; Sung, P.J.; Yen, M.H.; Chen, J.J. Garcimultiflorone G, a novel benzoylphloroglucinol derivative from Garcinia multiflora with inhibitory activity on neutrophil pro-inflammatory responses. Chem. Biodivers. 2014, 11, 819-824. [CrossRef]

20. Cheng, L.Y.; Tsai, Y.C.; Fu, S.L.; Cheng, M.J.; Sung, P.J.; Chung, M.I.; Chen, J.J. Acylphloroglucinol derivatives from Garcinia multiflora with anti-inflammatory effect in LPS-induced RAW264.7 macrophages. Molecules 2018, 23, 2587. [CrossRef]

21. Yang, C.S.; Huang, H.C.; Wang, S.Y.; Sung, P.J.; Huang, G.J.; Chen, J.J.; Kuo, Y.H. New diphenol and isocoumarins from the aerial part of Lawsonia inermis and their inhibitory activities against NO production. Molecules 2016, 21, 1299. [CrossRef]

22. Yang, C.S.; Chen, J.J.; Huang, H.C.; Huang, G.J.; Wang, S.Y.; Sung, P.J.; Cheng, M.J.; Wu, M.D.; Kuo, Y.H. New benzenoid derivatives and other constituents from Lawsonia inermis with inhibitory activity against NO production. Molecules 2017, 22, 936. [CrossRef] [PubMed]

23. Zhou, K.; Wunsch, C.; Dai, J.; Li, S.M. Gem-Diprenylation of acylphloroglucinols by a fungal prenyltransferase of the dimethylallyltryptophan synthase superfamily. Org. Lett. 2017, 19, 388-391. [CrossRef] [PubMed]

24. Tian, W.J.; Qiu, Y.Q.; Chen, J.J.; Yao, X.J.; Wang, G.H.; Dai, Y.; Chen, H.F.; Yao, X.S. Norsampsone E, an unprecedented decarbonyl polycyclic polyprenylated acylphloroglucinol with a homoadamantyl core from Hypericum sampsonii. RSC Adv. 2017, 7, 33113-33119. [CrossRef]

25. Tian, W.J.; Yu, Y.; Yao, X.J.; Chen, H.F.; Dai, Y.; Zhang, X.K.; Yao, X.S. Norsampsones A-D, four new decarbonyl polycyclic polyprenylated acylphloroglucinols from Hypericum sampsonii. Org. Lett. 2014, 16, 3448-3451. [CrossRef] [PubMed] 
26. Dharmaratne, H.R.W.; Napagoda, M.T.; Tennakoon, S.B. Xanthones from roots of Calophyllum thwaitesii and their bioactivity. Nat. Prod. Res. 2009, 23, 539-545. [CrossRef]

27. Rao, H.; Ma, X.; Liu, Q.; Li, Z.; Cao, S.; Li, C.J. Metal-free oxidative coupling: Xanthone formation via direct annulation of 2-aryloxybenzaldehyde using tetrabutylammonium bromide as a promoter in aqueous medium. Adv. Synth. Catal. 2013, 355, 2191-2196. [CrossRef]

28. Ishida, Y.; Shirota, O.; Sekita, S.; Someya, K.; Tokita, F.; Nakane, T.; Kuroyanagi, M. Polyprenylated benzoylphloroglucinol-type derivatives including novel cage compounds from Hypericum sampsonii. Chem. Pharm. Bull. 2010, 58, 336-343. [CrossRef]

29. Saranya, P.; Geetha, A.; Selvamathy, S.N. A biochemical study on the gastroprotective effect of andrographolide in rats induced with gastric ulcer. Indian J. Pharm. Sci. 2011, 73, 550-557.

30. Wu, H.; Zhao, G.; Jiang, K.; Li, C.; Qiu, C.; Deng, G. Engeletin alleviates lipopolysaccharide-induced endometritis in mice by inhibiting TLR4-mediated NF-kB activation. J. Agric. Food Chem. 2016, 64, 6171-6178. [CrossRef]

31. Benoit, M.; Desnues, B.; Mege, J.L. Macrophage polarization in bacterial infections. J. Immunol. Res. 2008, 181, 3733-3739. [CrossRef]

32. Pauleau, A.L.; Rutschman, R.; Lang, R.; Pernis, A.; Watowich, S.S.; Murray, P.J. Enhancer-mediated control of macrophage-specific arginase I expression. J. Immunol. 2004, 172, 7565-7573. [CrossRef] [PubMed]

33. Yang, Z.; Ming, X.F. Functions of arginase isoforms in macrophage inflammatory responses: Impact on cardiovascular diseases and metabolic disorders. Front. Immunol. 2014, 5, 533. [CrossRef] [PubMed]

34. Liao, X.; Sharma, N.; Kapadia, F.; Zhou, G.; Lu, Y.; Hong, H.; Paruchuri, K.; Mahabeleshwar, G.H.; Dalmas, E.; Venteclef, N.; et al. Krüppel-like factor 4 regulates macrophage polarization. J. Clin. Investig. 2011, 121, 2736-2749. [CrossRef] [PubMed]

35. Kaminska, B. MAPK signalling pathways as molecular targets for anti-inflammatory therapy from molecular mechanisms to therapeutic benefits. Biochim. Biophys. Acta 2005, 1754, 253-262. [CrossRef]

36. Liu, T.; Zhang, L.; Joo, D.; Sun, S.C. NF-kB signaling in inflammation. Sig. Transduct. Target. Ther. 2017, 2, 1-9. [CrossRef]

37. Abarikwu, S.O. Kolaviron, a natural flavonoid from the seeds of Garcinia kola, reduces LPS-induced inflammation in macrophages by combined inhibition of IL-6 secretion, and inflammatory transcription factors, ERK1/2, NF-kB, p38, Akt, pc-JUN and JNK. Biochim. Biophys. Acta Gen. Subj. 2014, 1840, 2373-2381. [CrossRef]

38. Johansson, M.; Köpcke, B.; Anke, H.; Sterner, O. Biologically active secondary metabolites from the ascomycete A111-95. 2. Structure elucidation. J. Antibiot. 2002, 55, 104-106. [CrossRef]

39. Mosmann, T. Rapid colorimetric assay for cellular growth and survival: Application to proliferation and cytotoxicity assays. J. Immunol. Methods 1983, 65, 55-63. [CrossRef]

40. Lai, J.L.; Liu, Y.H.; Liu, C.; Qi, M.P.; Liu, R.N.; Zhu, X.F.; Zhou, Q.G.; Chen, Y.Y.; Guo, A.Z.; Hu, C.M. Indirubin inhibits LPS-induced inflammation via TLR4 abrogation mediated by the NF-kB and MAPK signaling pathways. Inflammation 2017, 40,1-12. [CrossRef]

Sample Availability: Samples of the compounds are available from the authors.

(C) 2020 by the authors. Licensee MDPI, Basel, Switzerland. This article is an open access article distributed under the terms and conditions of the Creative Commons Attribution (CC BY) license (http://creativecommons.org/licenses/by/4.0/). 